University of Louisville

ThinkIR: The University of Louisville's Institutional Repository

\title{
An analysis of gentrification's effects on LGBTQ+ populations in Louisville, Kentucky.
}

Landon $\mathrm{H}$. Lauder

University of Louisville

Follow this and additional works at: https://ir.library.louisville.edu/honors

Part of the Other Political Science Commons, and the Urban Studies Commons

\section{Recommended Citation}

Lauder, Landon H., "An analysis of gentrification's effects on LGBTQ+ populations in Louisville, Kentucky." (2017). College of Arts \& Sciences Senior Honors Theses. Paper 128.

http://doi.org/10.18297/honors/128

This Senior Honors Thesis is brought to you for free and open access by the College of Arts \& Sciences at ThinkIR: The University of Louisville's Institutional Repository. It has been accepted for inclusion in College of Arts \& Sciences Senior Honors Theses by an authorized administrator of ThinkIR: The University of Louisville's Institutional Repository. This title appears here courtesy of the author, who has retained all other copyrights. For more information, please contact thinkir@louisville.edu. 
An Analysis of Gentrification's Effects on LGBTQ+ Populations in Louisville, Kentucky

By

\author{
Landon Hayes Lauder
}

Submitted in partial fulfillment of the requirements

for Graduation summa cum laude

and

for Graduation with Honors from the Department of Political Science

University of Louisville 


\title{
Lay Summary
}

This study looks to examine gentrification's-the process of changing a place's socioeconomic value to that of a higher level-relationship with identified $L G B T Q+$ spaces in Louisville from 1980 to present day. I use a particular methodology in urban studies that analyzes data pertaining to property values and demographics to assess gentrification. Once I establish which locations have a relationship with gentrification and what that relationship is, I use the data sets in comparison with each other to comment on potential class differences amongst the Louisville LGBTQ+ community and their ability to claim, maintain, and/or participate in $L G B T Q+$ space.

\begin{abstract}
This study attempts to examine and the analyze the process of gentrification amongst identified LGBTQ+ spaces in Louisville, Kentucky from 1980 to present day using both production-side and consumption-side methods derived from property values and census data, respectively. Using these data, I trace the development of these spaces and determine what relationship to gentrification they may have. I then compare production-side data with consumption-side data to determine disparities amongst class in potential LGBTQ+ bar patrons in Louisville, Kentucky.
\end{abstract}

Keywords and concepts: Gentrification, LGBTQ+, Louisville, Class 
An Analysis of Gentrification's Effects on LGBTQ+ Populations in Louisville, Kentucky

\section{$\underline{\text { Introduction }}$}

Louisville's recent declaration by Orbitz as number four out of the " 10 hottest gay destinations for 2016 " in the entire world has attracted considerable attention to the LGBTQ+ ${ }^{1}$ areas in town (Heidemann, 2015). Despite only receiving this distinction last year, Louisville has had a strong history of affiliated and openly LGBTQ+ spaces, mostly with bars and nightclubs. (I use the term "affiliated" to refer to spaces that do not explicitly claim a specific LGBTQ+ identity, yet are still LGBTQ+ welcoming or seen as an LGBTQ+ place by members of the community.) Additionally, the Human Rights Campaign has given Louisville a 100\% score on LGBTQ rights two years in a row (Bailey, 2016). Louisville now hosts two large LGBTQ+ pride events, Kentuckiana Pride and the Louisville Pride Festival. These LGBTQ+ distinctions for Louisville paint the city as a welcoming environment for LGBTQ+ folk; however, an analysis of gentrification in these spaces can draw attention towards economic class differences within the LGBTQ+ community in who can claim, maintain, and even participate in these spaces.

Gentrification - the process by which a space's socioeconomic status changes to a higher value - is occurring in Louisville, as in other urban areas. More specifically, gentrification affects—and in some cases is driven by—LGBTQ+ spaces. This thesis explores how gentrification affects these spaces, potentially contributing to an economic disparity amongst who can and cannot access these areas.

\footnotetext{
${ }^{1}$ In using the acronym "LGBTQ+," I am referring to Lesbian, Gay, Bisexual, Trans, and Queer, while the plus symbol includes identities of the longer acronym "LGBTQIPA2S," specifically Intersex, Pansexual, Asexual, and the North American Indigenous Two Spirit.
} 
I use Louisville as a case study due to my familiarity with the city and the overall lack of academic literature concerning Louisville. Studies on gentrification are numerous. However, none have studied Louisville, or paid much attention to moderate-sized cities in the southern region of the United States. I specifically focus upon the central business district (zip code 40202) and the Highlands neighborhood (zip code 40204) due to their historic and present LGBTQ+ importance. This thesis seeks to add to the already-existing gentrification literature by adding the lenses of Louisville and its LGBTQ+ community.

This thesis will use data concerning demographics and property values, the archival records of the local newspaper, the Courier-Journal, and the Williams-Nichols collection in the University of Louisville Archives (an LGBTQ+ archive of Louisville). With this information, this thesis will attempt to determine what role gentrification played and continues to play in affiliated and openly LGBTQ+ spaces in Louisville. In order to assess these claims, I first develop a framework of analysis based on scholarship concerning LGBTQ+ folk and urban space and the definitions of gentrification, and then examine the collected data.

Urban space embodies a contentious competition between claiming and maintainingbeing visible or present - and transformation - the physical change of space and resulting socioeconomic implications. Especially important to note are the difficulties faced by certain citizens who are unequally impacted by the claiming and transformation of urban space. For example, before the Civil Rights Act of 1964 and the Fair Housing Act of 1968, persons of color were barred from equal participation or even equal existence in urban spaces. Currently, LGBTQ+ individuals can be discriminated against in public accommodations, housing, and businesses in the United States, which makes participating and openly claiming spaces difficult. While 19 states have passed antidiscrimination laws based on gender identity and sexual orientation (and an 
additional 2 states only based on sexual orientation), these laws are still not the norm of the United States (ACLU, 2017). As such, urban space for LGBTQ+ persons can be difficult to claim and/or maintain.

After discussing the tensions amongst urban space, I draw on research to establish a workable definition of gentrification, about which there is relatively little conflict. However, academic literature concerning how to measure gentrification is more nuanced. I present the main tenets of the primary ways by which gentrification is measured. The methods section follows the literature review and I outline the types of data I will be using to piece together a more holistic picture of gentrification in specific locales in Louisville, and exactly how those locations were determined relevant. Finally, I will analyze this data within the existing literature in the topics of gentrification and urban space to conclude that gentrification-a socioeconomic process-is occurring in Louisville LGBTQ+ spaces, contributing to a class-based division amongst LGBTQ+ folk in Louisville. 


\section{The Construction of Urban Space}

\section{Cities, Identity, and Space}

Cities are uniquely positioned to provide areas in which identities can be expressed. The population of and differences amongst urban citizens provide for the possibility of mapping these differences onto space (Tonkiss, 2005 p. 108). This phenomenon can be seen when urban areas contain several various ethnic restaurants, dance clubs, neighborhoods, and the like when compared to less urban areas.

This mapping of identities onto urban space becomes more complex when urban space is understood as a commodity. Land, when controlled by a state entity-city government, for example — is sold and taxed at a certain amount. Due to this commodification of land, urban space becomes available for those who are able to afford to claim (purchase) and maintain (pay taxes, make improvements, etc.) these tracts of land. When speaking specifically about commodified non-straight space, urban affairs literature notes how there are large distinctions between various intersecting identities ${ }^{2}$ within non-straight sexuality in their ability to claim and transform urban space (and in some cases, even participate). Lawrence Knopp (1998) succinctly stresses this intertwinement: "The forging of identities through the economic and political colonization of territorial spaces (and the related creation of gay-identified places) is much facilitated by class, racial, and gender privilege," (p. 159; emphasis original).

\footnotetext{
${ }^{2}$ I use the phrase "intersecting identities" to mean the multiplicity of identifiers an individual may claim as parts of their identity (i.e. race, ethnicity, sexuality, gender identity, etc.). For more information on intersectionality, see Williams, K. (1989). Demarginalizing the intersection of race and sex: A black feminist critique of antidiscrimination doctrine, feminist theory and antiracist politics. The University of Chicago Legal Forum (140), 139-167.
} 
White men are the most able to claim urban space due to experiencing the least amount of structural barriers to economic participation (Tonkiss, 2005, p. 108). When considering sexual orientation, gay white men may have had more structural barriers to claiming and participating in urban space. This is particularly true before laws barring discrimination based on sexual orientation were codified in some cities and states. However, even amongst non-straight folk, white gay men still have the most economic privilege (Knopp, 1998; Brown-Saracino, 2009). Using this power over space, gay white men have been able to craft spaces that perpetuated "their particular sexualities as well as the perpetuation of other structures of oppression," (Knopp, 1995, p. 158; emphasis original). Thus, in the process of claiming non-straight space, gay white men have been creating spaces that might be exclusionary for other minorities. In contrast to white gay men, lesbians have had their share of difficulty in claiming urban space.

There are several explanations as to why lesbian claims to urban space remain small in number when compared to space claimed by gay men. Lauria and Knopp (1985/2010) reason that lesbians have not been subjected to the same forced awareness of their sexuality as men have, which results from the expected subjugation of women and repression of sexual difference in highly masculine environments (p. 276). As such, they argue, gay men have faced more sexual surveillance and punishments if they deviated from the heterosexual norm, creating "the need to escape to an oasis of tolerance; the need for a sense of place and belonging; and the need to develop economic and political clout as a community," (Lauria \& Knopp, 1985/2010, pp. 277-278). Another argument for why lesbians have not been as prolific in claiming urban space rests upon traditional expectations of women in general: "Lesbian geographies can be harder to map...given that women are less likely to than men to own businesses or homes, generally have less disposable income or time for cultural consumption, and can feel more vulnerable to violence or harassment 
in public," (Tonkiss, 2005, p. 107). An exact answer to the question of the imbalance in number between gay and lesbian spaces may remain dependent upon the particular context.

Overall, urban spaces that are solely denoted by sexual orientation become quite distinct: "Sexuality only becomes marked in space when it is non-straight. Heterosexuality, in contrast, is like white noise in the urban environment," (Tonkiss, 2005, p. 96). Due to its marking in cities, non-straight spaces are subjected to the commodified nature of urban space:

Sexual 'others' are also clearly constructed as agents of consumer citizenship-not least given the pink economy discourse, plus the discussions of global gay tourism, the globalization of Pride/Mardi Gras mega-events and so on...other sexual 'others' are constructed as exotic objects to be consumed, perhaps most vividly in forms of sex tourism.... The new publicity of more mainstream manifestations of gay consumer cultures - thoroughfares, street cafés, trendy bars, themed gay villages - has driven the less-assimilated queers underground. (Bell \& Binnie, 2006, pp. 179-180)

Non-straight sexual orientations in cities, whether solely "sexual 'others," or "other sexual 'others," are subjected to commodification and consumption power, "reducing the 'gay public sphere' to consumption spaces and gentrified neighborhoods," (Bell \& Binnie, 2006, pp. 180-181; emphasis added). Thus, commodification plays a large role in constructing non-straight space in urban areas.

While urban space may accommodate the many identities that participate within it, the ability to claim and maintain urban space is largely dependent upon the economic privilege these participants possess. Taking into consideration the commodified nature of place, there arises a multifaceted understanding of urban space that involves race, class, gender, and sexual orientation that all influence the ability to claim, modify, or even participate in space. When specifically focusing upon non-straight space in urban areas, the commodified nature of space becomes apparent since these places become reduced to their level of marketability. Thus, when considering non-straight urban space, class becomes a crucial factor in its analysis. 


\section{Limitations on Intersectionality}

While urban studies consider gay and lesbian identities in cities, specific scholarship on trans and gender queer or nonconforming individuals within the realm of critical urban space is lacking. Since gender identity and sexual orientation are not the same (although they intersect), the literature previously examined collapses trans individuals into straight and non-straight sexual orientations. It also renders gender non-conforming individuals unintelligible, since the scholarship tends to examine gay and lesbian sexual orientations that depend on a binary or at least a static gender identity. By focusing on gay and lesbian individuals, it also leaves out specific mentions of other sexual orientations such as pansexuality, bisexuality, asexuality, etc. While these sexual and gender identities are very important, the literature and the data available for this thesis do not provide a clear path by which to specifically comment on these individuals.

Furthermore, while the literature presented throughout does at times include race as a factor in claiming urban space amongst non-straight individuals, this thesis focuses solely on class and its direct intersection with the LGBTQ+ community. While race certainly does play a large role in questions of class and general socioeconomic conditions of a city, the mixed methods used and limited information available for this thesis prevents the ability to directly examine the aspect of race in gentrification amongst the specific locales used. Thus, the scope of the thesis is restricted to focus on indicators of class position as it is directly related to gentrification of non-straight space in Louisville. 


\section{Definitions of Gentrification}

The first academic use of the word gentrification was in Ruth Glass's 1964 book London: Aspects of Change, where she remarked: "One by one, many of the working class quarters of London have been invaded by the middle classes - upper and lower," (Glass, 1964/2010 p. 7). Glass had observed the conversion of homes, and even entire neighborhoods, from being occupied by working-class people to becoming "elegant, expensive residences," and then even subdivided into smaller, luxury apartments (Glass, 1964/2010, p. 7). This class conversion in both the occupancy of residences and the built environment continues throughout the entire area "until all or most of the original working class occupants are displaced, and the whole social character is changed," (Glass, 1964/2010, p. 7). Glass's definition of gentrification includes changes in the built environment, displacements of working-class members, and the entire socioeconomic transformation of an area. These characteristics can be found in the flurry of scholarship which followed her original study.

\section{Gentrification as Class Conversion and Displacement}

In the foundational literature of gentrification, socioeconomic changes in an area and the resulting displacement of those not able to afford changes in both the built and social environment are the most consistent and highlighted features. Thus, gentrification is broadly understood as a transformative process, where one socioeconomic class transforms space to reflect their status, resulting in a change of the entire socioeconomic makeup of the space. This is the main tenet of Glass's (1964/2010) academic and methodological account used above, understanding gentrification as a function of class disparities in who can claim an area, who can transform it, and who loses at the hand of this process. 
Socioeconomic class and displacement are also characteristics found in Eric Clark's definition of gentrification. Clark (2005/2010) understands gentrification as a process of displacement of one class over another in urban space:

Gentrification is a process involving change in the population of land-users such that the new users are of a higher socio-economic status than the previous users, together with an associated change in the built environment through a reinvestment in fixed capital. (p. 25)

Clark then further explains the specific reasons why class plays such a large role.

In formulating his definition of gentrification, Clark reveals what he believes to be the underlying reasons for this process of investment and displacement: commodification, power relations, and the "vagrant sovereign," (Clark, 2005/2010, p. 24). Clark goes so far as to suggest that the "tandem dynamic" between land commodification and power relations produces gentrification as a process of colonization; in this view, certain groups, possessing more power or ability in economic, political, and judicial realms, are able to make more claims to land use (Clark, 2005/2010, p. 27). Yet, what truly ties commodification and power together is the vagrant sovereign. To explain the term, Clark turns to Wendell Berry: "Generation after generation, those who intended to remain and prosper where they were have been dispossessed and driven out...by [the vagrant sovereigns] who were carrying out some version of the search for El Dorado," (Wendell Berry as quoted in Clark, 2005/2010, p. 27). The vagrant sovereign is thus an individual who possesses the ability to roam freely, locate a specific place, and transform it to their liking. This description aptly summarizes how Clark views gentrification as a process carried out by people who can afford to make claims to urban space, transform it, and thus change the character of the entire area.

Robert Beauregard (1986) also highlights class as a critical understanding of gentrification by describing in great detail who the gentrifier is. He does this by identifying their demographics, 
namely their occupations and their income and consumption habits. With the decline in manufacturing-sector jobs after World War II and the rise of the "professional-managerial" class of occupations, "It is within this urban, professional-managerial fraction of labor that the gentrifiers are situated," (Beauregard, 1986, p. 42). Beauregard (1986) claims the gentrifiers' consumption preferences "[are] partly one of conspicuous consumption, the acquisition of commodities for public display," (p. 43), As such, the gentrifier typically consumes goods and services outside of the home and wishes to live near such commodities (Beauregard, 1986, pp. 4546).

Furthermore, Beauregard (1986) describes the more physical aspects of gentrification (or the built environment). One method by which buildings become appealing to gentrifiers is when stable working-class neighborhoods, because of their low cost in comparison to the rest of the city, attract gentrifiers of a higher socioeconomic class to claim and remodel (Beauregard, 1986, pp. 47-48). Another way buildings become targets of gentrifiers is due to the suburbanization in the early and mid 1900s, which left a surplus of middle-class housing within the city limits vacant; due to declining value, there were swaths of cheap housing (Beauregard, 1986, p. 50). Beauregard (1986) continues his examination of gentrification of buildings into the still-popular phenomenon of loft conversions, where abandoned or derelict manufacturing facilities and warehouses can be converted into stylish lofts after large investments of capital (p. 48-49). These descriptions of buildings that gentrifiers usually target maintains the central importance of class and the transformation of the built environment in gentrification literature, where those of a higher socioeconomic class are able to target working-class areas and convert them to their liking.

Similar to Eric Clark's (2005/2010) detailed analysis of displacement in gentrification, Beauregard (1986) also invokes the power dynamics between the potential gentrifiers and the 
original inhabitants of the urban space in question, mostly drawing upon the consumption power of the two groups. The original inhabitants of an area targeted for gentrification typically lack the consumption ability of the potential gentrifiers, "and thus their attractiveness to proponents of redevelopment...is also weak," (Beauregard, 1986, p. 50). Furthermore, the original occupants of the urban space typically require "a greater share of local governmental services," (Beauregard, 1986, p. 50). Beauregard (1986) stitches together the original occupants' inability to consume at high levels and their reliance upon social services to comment upon their overall power: "these individuals and families lack economic power, and because of related disadvantages in the realms of consumption and reproduction...they also lack political power," (p. 50). This lack in economic and political power renders this group susceptible to the overpowering of gentrification and the gentrifiers, and thus the previous occupants become displaced as a result (Beauregard, 1986).

While these three main conceptions of gentrification are not completely exhaustive of the entire field of literature concerning this topic, they nonetheless present stable, workable definitions and understandings of the transformative process of gentrification. The foundations of gentrification, rooted in socioeconomic transformations of urban space, provide the groundwork upon which measures of gentrification can be operationalized and measured. 


\section{Measuring Gentrification: Production versus Consumption}

While little disagreement exists in the literature concerning the broad definition of gentrification as a process of changing a neighborhood's socioeconomic position and the built environment of place, a sharp split amongst scholars emerges on how exactly to measure these neighborhood changes. One view, described as an adaptation of production-side economics, seeks to understand gentrification as a process of investments that affect the land value of a place. The other view, a consumption-side explanation, believes gentrification can be measured by documenting the changes in consumption factors, such as education, age, market values for goods and services in the area, etc. (Neil Smith \& Peter Williams, 1986). I do not seek to adjudicate these positions. Rather, I use these arguments to create a methodology that can describe gentrification in the central business district and the Highlands neighborhood from two perspectives. This methodology will provide an overall image of whether or not gentrification has occurred in these areas and the selected bars/nightclubs affiliated with the LGBTQ+ community in Louisville.

\section{Production-Side Measures of Gentrification and the Rent Gap Theory}

One way to measure gentrification is to critically examine how property itself becomes produced by capital investments. Stated by Neil Smith and Peter Williams (1986): "Gentrification, according to this perspective, results from the private and public investment of capital in certain land uses, its devaluation through use and disinvestment, and the resulting opportunity for profitable reinvestment that is thereby created," (p. 4). In short, production-side measures seek to analyze the direct impact of capital on fixed urban space.

The mechanism by which production-side measures can be understood is called the "rent gap theory," which was first established in academia by Neil Smith, a critical geographer, in 1979: "The rent gap is the disparity between the potential ground rent level and the actual ground rent 
capitalized under the present land use," (p. 545). The potential ground rent to which Smith is referring is simply the " "highest and best use"” of a particular parcel of land (Smith, 1979, p. 543). For example, a solidly built structure, perhaps situated in a valuable section of town, has the potential, after investment, to be repurposed into something functional. The ground rent level Smith uses in his definition is the same piece of land's value of its present use, before any sales or purchases of the property. Thus, the production-side measure of gentrification is best explained as a gap between the present value of the land (taking into consideration the current operations, if any) and the potential seen in that same land once improvements are made. Measuring these two values comprises the definition of gentrification involving property enhancements (Glass, 1964/2010; Smith, 1979; Smith \& Williams, 1986; Smith, 1987; Beauregard, 1986; Clark 2005/2010).

For a property's "highest and best use" to be realized (and thus its potential ground rent), there must be a series of direct capital investments in the property, which can take the form of anything from demolition and rebuilding to making changes in the façade of a building (Smith, 1979; Smith \& Williams, 1986; Smith, 1987; Clark, 1995; Clark, 2005/2010). To operationalize this measure, several studies have used property records or tax assessments based on these property values of particular locations that denote some sort of value of improvements made to the property (Hammel, 2013). Furthermore, some have called for specifically using property values to operationalize the potential ground rent, as this data reveals the exact value of the property improvements of a piece of land (Lauria \& Knopp, 1985/2010). As for the capitalized ground rent measures, the same studies examining property values (Hammel, 2013) used approximately the same measures of property values/property value tax assessments, but instead of looking at 
property improvements, examined the value of the land prior to development, to obtain an approximate measure of the total value of operations on the land if it were sold.

Thus, the rent gap of properties, hereafter referred to as the production-side factors of gentrification, have been previously measured by examining the amount of fixed-capital investments of a property (its potential ground rent) and its value without such improvements (its capitalized ground rent) through the use of property records. The gap between these values and any large shifts in these numbers over time should yield an answer as to whether a property has been gentrified or is gentrifying. Yet, to measure gentrification solely from a production-side perspective would be doing gentrification analysis a grave injustice.

\section{Consumption-Side Measures of Gentrification}

Another way to measure gentrification is by analyzing the consumption patters of the citizens of a given area (Smith 1979; Smith \& Williams, 1986; Beauregard, 1986; Smith, 1987; Clark, 1995; Clark, 2005/2010). This measure complements production-side measures of gentrification, rather than compacting with them: "It is this combination of social, physical, and economic change that distinguishes gentrification as an identifiable process or set of processes," (Smith, 1987, p. 463). Consumption-side measures of gentrification thus attempt to operationalize these social changes in particular areas of neighborhood change.

Consumption measures for gentrification analysis operate on the premise that as housing and land markets in cities are capitalized, and as citizens have the ability to participate and even move in between areas with preferred consumable goods and service, that changes in an area reflect these preferences (Beauregard 1986; Smith \& Williams, 1986). In one of the most detailed epistemological accounts of consumption-side measures for gentrification, Beauregard (1986) sets the stage for operationalizing consumption-side measures for gentrification that have remained an 
essential tool for any analysis concerning gentrification. In his account, factors such as age, income, number of children in the home, and occupational classification (amongst other factors) can influence the types of properties favored by certain types of people (Beauregard, 1986). In other words, one's ability to consume goods and services and to invest in property can directly influence the types of space created and frequented. 


\section{$\underline{\text { Methods }}$}

To understand how affiliated and openly LGBTQ+ space is claimed and potentially gentrified in Louisville, this thesis compares different measures of gentrification in two locations over approximately thirty years, from 1980 to present day. The locations (the central business district and the Highlands neighborhood) were chosen based on their overall level of economic activity and their salience in having an LGBTQ+ presence. The time period of 1980 to present day was chosen due to the height of openly claiming LGBTQ+ space in urban areas being in the 1980s, as many gay individuals began to carve out bars in downtown business districts (Doan \& Higgins, 2011), and their visible presence today. Lastly, both the production-side and consumption-side measures of gentrification used in this analysis reflect the current publically available information for these spaces. With these data, I compare the selected locations over an historical time frame to analyze what gentrification-an economic phenomenon-could potentially mean for the LGBTQ+ individuals in Louisville.

\section{Consumption Measures}

I will be measuring gentrification from both consumption-side and production-side perspectives in order to provide a more holistic picture of the openly and affiliated LGBTQ+ bars in Louisville. I will use publically available and free census data from the U.S. Census Bureau to describe consumption-side explanations.

In the census data, I pay particularly close attention to the numbers for higher education, labor force, occupation, and median income compared to the city population as a whole. These 
census categories reflect the influences on consumption power found in current and past literature concerning consumption-side explanations for gentrification. ${ }^{3}$

While it would be considered best practice to use neighborhood-specific census data to truly capture any socio-economic changes relevant to consumption patterns, no such consistent data for Louisville exists over the thirty-year timespan. As such, census information was obtained and analyzed from the United States Census Bureau's website, where census information from 1790 to 2010 is in an electronic format. Until the release of "American Fact Finder" in the Census Bureau, specific neighborhoods and zip code data is largely not available, especially for Kentucky. Since Kentucky's most detailed census data was not further subdivided than "Urbanized Areas"4 and "Standard Metropolitan Statistical Areas," (SMSA) until 2010, I instead use data from the "KY part" of the Louisville-Indiana "Urbanized Area," as it most closely reflects the boundaries of Louisville today.

Even without specific neighborhood distinctions, the aggregate information for Louisville is still relevant and crucial for an analysis of the consumption factors that drive the process of gentrification over time. The limited census data for 1980 to 2010 will mostly be used to show the amount of macro-level changes over the entire time period being examined in this work. The largescale measure of consumption measures will be used to compare the place-specific changes in

\footnotetext{
${ }^{3}$ It is important to note that in the representations of the data in the tables use the exact language found in the respective census - no alterations were used.

${ }^{4}$ The definition provided by the U.S. Census Bureau in the 1980 census for "Urbanized Areas" includes both the city boundaries and adjacent areas that have specific requirements for density to be included. See the 1980 Census, Appendix A, pages 2-3for more information. ${ }^{5}$ The definition provided by the U.S. Census Bureau in the 1980 census for "Standardized Metropolitan Statistical Areas" follows the general guidelines of: "a large population nucleus, together with adjacent communities which have a high degree of economic and social integration with that nucleus," See the 1980 Census, Appendix A, page 3.
} 
production-side measures. This comparison will show how if gentrification is occurring, to what degree can the citizens as a whole participate in these gentrified areas.

\section{Difficulties in Comparisons: The Louisville Merger}

In November of 2000, Louisville city and Jefferson County merged to become one urban area under a single government, the Louisville-Jefferson County Metropolitan Government (McDonough, 2000). This consolidation introduces a difficulty in the ability to analyze population statistics, as each census will contain different geographic boundaries and definitions for SMSAs, Urbanized Areas, and the city

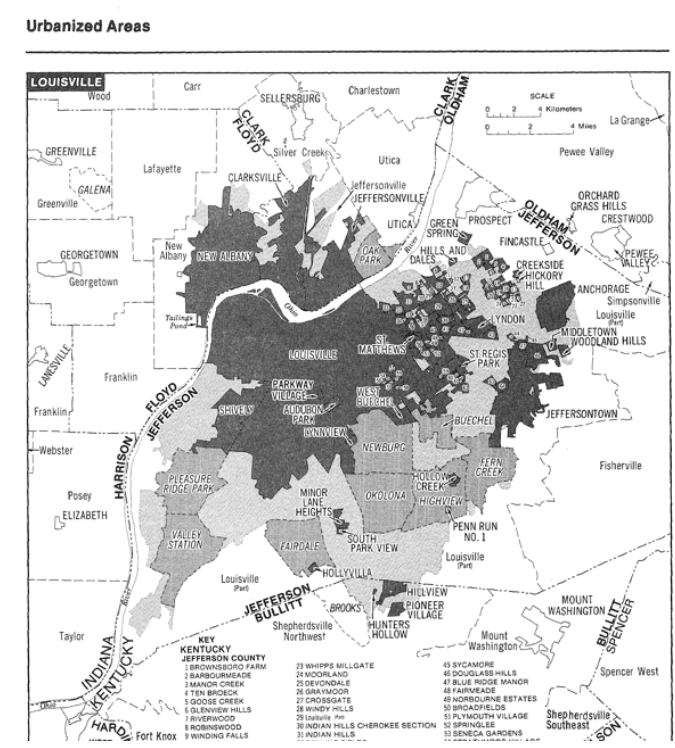

Figure 1: Picture representing the 1980 Census's "Urbanized Area" for Louisville

itself. In order to keep the data to scale of the present Source: 1980 Census, p. [19-45] for comparison, the data used in each table will reflect the closest data for Jefferson County as a whole. Accordingly, the data used in the 1980, 1990, and 2000 censuses will include that of the Kentucky-only part of the defined "Urbanized Area" found in Figure 1.0. (This figure is replicated in Appendix A for clarity).

\section{Census Data}

The census data from the 1980 census's “Urbanized Area” for Louisville included the areas mostly within Jefferson County in addition to the immediate bordering cities found in Southern Indiana; however, the actual numbers used are from the Kentucky-only part of the Urbanized Area. This is in close approximation to the population of today's Louisville Jefferson County consolidated unit. The information for Louisville city before the 2000 merger would be eliminating 
the areas eventually subsumed in the consolidation; on the other hand, the boundaries of the Louisville SMSA would be too large, as it includes several counties.

\section{Census Data}

The 1990 census retained the definition for "Urbanized Area" used in the 1980 census, and thus the data used in this analysis for 1990 was derived from the Urbanized Area designation for Louisville, and the Kentucky part only. ${ }^{6}$

\section{Census Data}

The 2000 Census Data presents a slight change in available data. The U.S. Census Bureau does not have the detailed demographic profiles for Urbanized Areas found in the previous two censuses. As such, I instead used the only available census data for the specific demographic information, which was the Kentucky-specific section of the census. This census breaks the locations down by county, which still approximately matches the Kentucky-specific portion of the Louisville Urbanized Area used in the previous censuses. Nevertheless, certain categories of information (i.e. education and occupation) are more limited than previous census data.

\section{Census Data}

The 2010 Census Data was the first census conducted after the Louisville city/Jefferson County merger. As such, the geographical census tract is smaller than the urbanized area found in previous census data. Therefore, the measures will be less in magnitude due to this smaller area. This large discrepancy in size renders the data difficult to compare by total numbers. Furthermore,

\footnotetext{
${ }^{6}$ See the 1990 Census, Appendix A, page 12.
} 
the data for the 2010 Census was placed onto a new web-based system of the Census Bureau, called "American Fact Finder," instead of large documents.

\section{Inflation}

In order to accurately compare incomes found in the census data used, the reported values in each census were converted to 2016 dollars using the U.S. Department of Labor's Bureau of Labor Statistics" "CPI Inflation Calculator."7 This will allow accurate analysis of the buying power and relative economic conditions in the most recently available, stable terms.

\section{Production Measures}

For production-side explanations of gentrification, I use online property valuation records from the Jefferson County Property Valuation Administrator's office (JPVA) (publically available, yet a service for which one must pay to access all records), in accordance with rent-gap theory. The property value data from the JCPVA is used because its division into two types-land value and property improvement value - is able to capture capitalized ground rent and the potential ground rent ("best and highest use") of particular spaces, respectively.

Specifically, I will present the land valuation, the property improvements valuation, and the combination of the two (the overall property valuation) for each property to the extent data is available; this data can be found in Table 5.0 in Appendix A. Curiously, there are no property records for these locations prior to approximately 1993. I will present what data are available and where such records are not available, I will try to trace the history of the property prior to and during the existence of these bars using news articles and the Courier-Journal archives.

\footnotetext{
${ }^{7}$ The CPI Inflation Calculator can be found at: http://www.bls.gov/data/inflation_calculator.htm
} 


\section{Identifying Place}

In order to determine which bars to examine in Louisville from 1980 to the 1990s, I used the bar flyer compilation found in the Williams-Nichols collection at the University of Louisville archives. These bar flyers were accumulated by various local LGBTQ+ activists over the span of several decades. I documented the location, name, and content of each flyer found in order to construct a large cultural map of bar locations in Louisville over this timeframe. Most of these bars fell in the 40202 zip code of Louisville, which is the central business district.

The more contemporary bars were chosen due to their current prominence in lay local knowledge, in addition to them being clustered in a self-proclaimed bohemian neighborhood in Louisville, home to numerous LGBTQ+-affiliated events in the 40204 zip code, the Highlands neighborhood. 


\section{Consumption-Side Data and Population Trends}

\section{General Population (Tables 1.0, 2.0, 3.0, \& 4.0 in Appendix A)}

The general population in Louisville fluctuated over the three census decades used in this data set. Nevertheless, it still holds that Louisville is a moderate-sized metropolitan area, with more than half a million people. Consistently, Louisville's majority racial group is white, followed by black or African American, and then Asian. The white, Asian, and Hispanic populations in the city increased over thirty years, while the black/African American population stayed relatively constant. Indigenous populations and other races are present, yet in quite low numbers. The general population data is used to compare the following other data sets.

\section{Education (Tables 1.1-1.2, 2.1-2.2, 3.1, \& 4.1-4.2 in Appendix A)}

Educational attainment in Louisville, specifically collegiate, has steadily increased over thirty years, starting at $17 \%$ of the total population that had completed any level of college, to $28 \%$ of the total population with a Bachelor's degree or higher currently. This demonstrates how, overall, more people in Louisville achieved higher education, and presumably developed a higher level of consumption with each increase in population with collegiate degrees. This logic follows the premise that with a higher education, one will most likely yield a higher income, which would influence consumption.

\section{Labor Force (Tables 1.3, 2.3, 3.2, \& 4.3 in Appendix A)}

Louisville's labor force over thirty years rose steadily, not abruptly. This indicates increases in the labor force follow the general increase in population. There was no severe drop or increase in Louisville's labor force, and employment remained above 90\%. Since there were no 
significant fluctuations, it can be assumed the amount of people with an income remained proportionately similar throughout thirty years.

\section{Occupation (Tables 1.4, 2.4, \& 4.4 in Appendix A)}

While the occupation data is absent from the accessible 2000 Census data, it can still be compared across the thirty-year timespan. The first occupation category, largely summarized as "management," is the occupation with the highest earning potential. Over time, this category increased more than 30,000, a larger comparative increase than the other occupation categories. The "sales" occupation classification remained the largest occupation category through all thirty years in Louisville, with relatively little changes in total numbers (except in 2010 due to the difference in the census tract size). Service occupations changed little during thirty years. The "farming" category was the smallest category, yet was not present in the 2010 census (it became included in the "nature" category). The "laborers" and "repair" occupational categories remained consistently sizeable, and in 2010 were lumped into two different categories ("construction" and "production" categories); however, these last two categories, when combined, are much smaller in size as the "repair" and "laborers" categories used in previous censuses.

Overall, the occupational shifts in Louisville from 1980 to 2010 show increases and stabilizations in very specific fields of work. The managerial class grew more so than any of the other occupations. However, in total number, the sales category of occupation remained the largest single category, employing somewhere near a third of the total civilian labor force. The combination of the managerial and sales categories represents around half of the total employed in Louisville and thus provides a solid and potentially high-consumption base for Louisville businesses. 


\section{Median Income (Tables 1.5, 2.5, 3.3, \& 4.4 in Appendix A; Figure 2)}

Median income for families, households, and nonfamily households fluctuated over thirty years. Overall, all median incomes in Louisville dropped; these trends can be seen in Figure 2 below. Family median income fell 3.4\% from 1980 to 1990 , followed by a $0.6 \%$ decrease from 1990 to 2000 . There was then a $6.5 \%$ decrease between 2000 and 2010 . Overall, family median incomes fell $2.7 \%$ from 1980 to 2010 . There was a similar pattern in household incomes. Between 1980 and 1990, household median income fell 8.7\% and then fell an additional 8.9\% from 1990 to 2000. Household median income decreased by $11.3 \%$ from 2000 to 2010 . From 1980 to 2010 , median household income fell a total of $11.8 \%$. Nonfamily household income (clear data for which is only available for 2000 and 2010), fell $11.1 \%$ from 2000 to 2010.

Overall, there was a decrease in all three measures of median income for Louisville from 1980 to 2010. This overall decrease in median incomes suggests the consumption ability of Louisville citizens is potentially decreasing over time, with no signs of long-term increases.

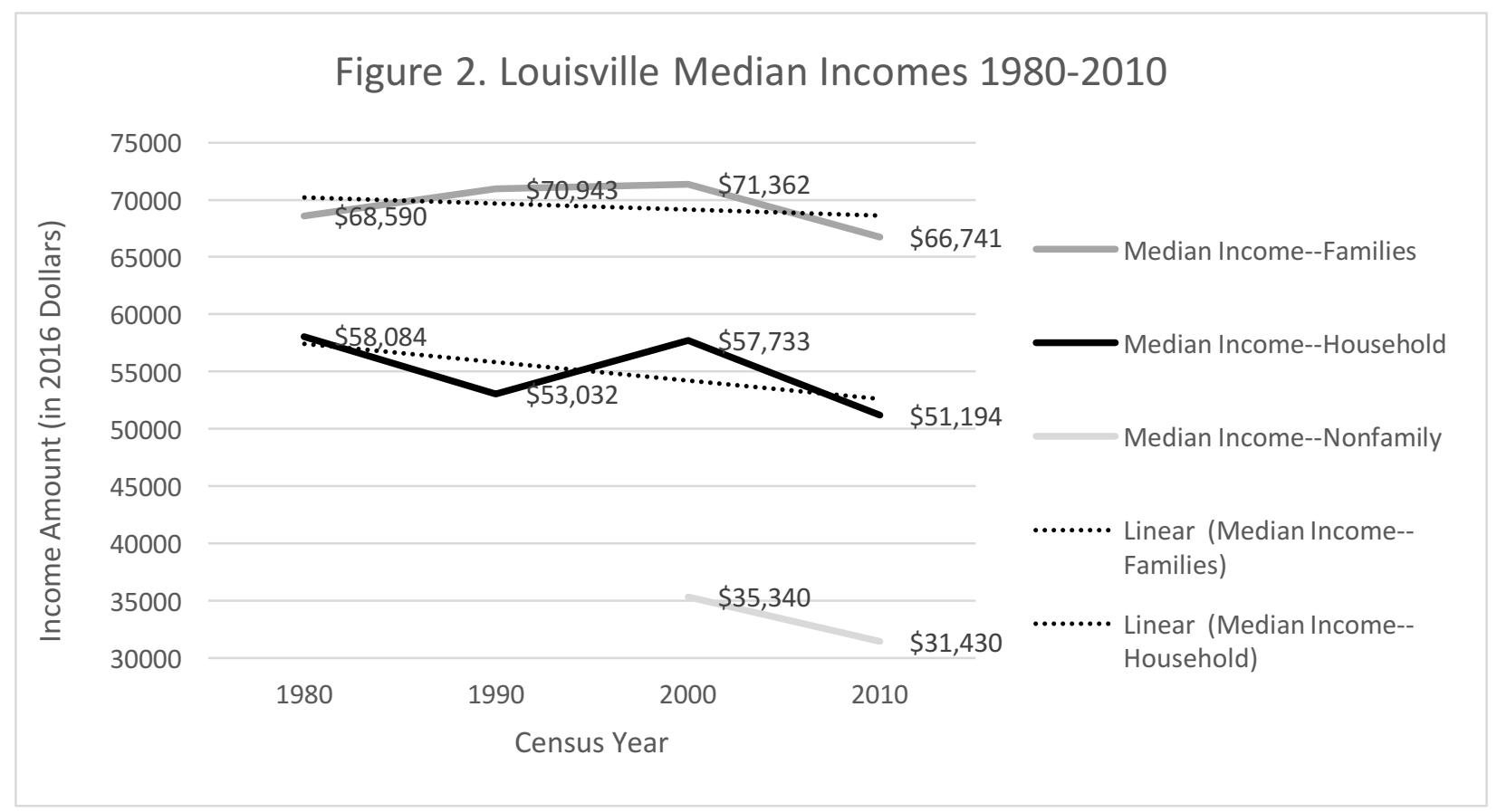

Source: U.S. Census Bureau 


\section{Production-Side Data: Central Business District}

Once a bustling hotspot of numerous openly LGBTQ+ bars and nightclubs, the central business district in Louisville now only hosts two extant LGBTQ+ bars, Play (located outside the parameters of this thesis) and Tryangles. Most of the bars flourished during the 1980s and the early half of the 1990s; by 1995 — and certainly by 2000 — they had largely vanished for various reasons. Unfortunately, due to a lack of property value assessments and specific neighborhood census data, it is impossible to conclusively deduce gentrification as the cause of their demise. Nevertheless, records both within the Williams-Nichols Collection and from the Courier-Journal reveal some insight as to why these bars closed.

\section{Tryangles}

Tryangles first applied for its liquor license in early 1994 and later that year opened its gay country-themed doors at 209 South Preston Street (Courier-Journal, 1994; Egerton, 1994a). While there are no property value assessments on record before 2001, excerpts from the Courier-Journal trace the location's history from 1980 until Tryangles occupied the place. In 1980, 209 S. Preston was “Mel Golde Men’s Shoes, Inc.” (Courier-Journal, 1980). However, in 1988, it became “Strasberg's Sportswear," (Courier-Journal, 1988). Ever since 1994, Tryangles has occupied the spot and has weathered a battering of gentrification.

While the period from 1994 to 2001 cannot be traced in property value assessments, the records from 2001 to 2014 show the massive acceleration of land value Tryangles has experienced in its location. In 2001 , the total assessment stood at $\$ 180,000$, with $\$ 108,000$ in land value and $\$ 72,800$ in property improvements. The overall assessment, including both land value and property improvements, increased slightly between 2001 and 2004 (see Table 5.0). However, the land value 
increased $220 \%$ by 2008 , with no change in property improvements from 2004 , which brought the total property valuation to $\$ 603,080$. Since this massive increase in value was in the fixed land and not property improvements, it is reasonable to suspect that the area surrounding Tryangles experienced a relatively quick wave of gentrification. This led to a domino effect of higher land valuation in the surrounding area. The assessment decreased in 2014 solely due to no documented property improvements being made. (The land value increased slightly to $\$ 477,130$ ).

\section{Bar Disappearances}

While Tryangles may be the last standing openly LGBTQ+ bar in the 40202 zip code, there were numerous others from 1980 through the 1990s. However, since there are barely any records for these locations from either the Jefferson County Property Valuation Administration or the Jefferson County Sheriff's Office, it is quite difficult, if not impossible to determine the production-side explanation of gentrification for these places. Nevertheless, using the CourierJournal archives and the Williams-Nichols collection, I trace the existence of each of the selected LGBTQ+-affiliated bars.

In this section, I detail the property history for the some of the most popular LGBTQ+ bars in the central business district from 1980 to approximately 1995 (and in one instance, to 2015). To designate "popular," I used the bar flyers and assorted documents in the Williams-Nichols collection. After performing a thorough review of all items contained in the "bar flyers" box of the collection, I tallied the number of instances a certain bar appeared in these documents. I argue the more mentions a bar has in the form of advertisements, the more popular the bar had become. Advertisements require capital and time to produce and disseminate such materials to the community; thus, more advertisements are presumably produced by more frequented bars that draw in more capital and have more resources. Additionally, the more popular the bar, the more it 
would be advertised over time. With this method, I determined the top five mentioned LGBTQ+ bars amongst the bar flyers in the 40202 zip code in Louisville. These were, in order from most to least mentioned, "Discovery Night Club and Bar;" "The Downtowner Complex;" "Tynker's" \& “Tynker's Too/The Rage;” “Connection;” and "Murphy’s Place/Murphy’s Upstairs.” Using this list, I conducted searches in the Courier-Journal archives to find any features for these bars, which would hopefully provide insight into the reasons for closing.

Beginning with the Discovery Nightclub and Bar, there are several mentions in the Courier-Journal in the 1980 s of its existence (i.e. featured in lists of activities in Louisville), but the search revealed no features for the bar beyond its namesake and address at 116 East Main Street. The bar flyers for Discovery go as far back as 1982 and stopped in 1992 with a Thanksgiving Day ad. While this is not a definitive timeline for the bar's existence, it suggests a rough timeframe. Today, the same place is registered as a commercial property, valued at a total of $\$ 981,730$.

The bar with the second highest amount of mentions in the Williams-Nichols collection is The Downtowner, also known as The Downtowner Complex, which consisted of several subunits, including a club and a showroom. The beginnings of The Downtowner at 105 West Main Street were in 1975, after the original Downtowner, built in 1953 as Louisville's first openly gay bar, burned $(\mathrm{Hu}, 2016)$. The [new] Downtowner served as a locus of LGBT organizing in the city, as it was the origin of the first LGBT coalition in Louisville. It also was subject of intense discriminatory actions by law enforcement, involving neglected investigations of a terrorist attack against the club and handling a common assault incident as a quarantine zone for assumed HIV contamination (Gil, 1985; Hu, 2016). The Downtowner experienced a potential wave of gentrification in the form of tremendous capital investments. In the mid 1980s, there was a large 
development effort of the block around the Downtowner, totaling \$35 million over 20 years (Shafer, 1984; Dumas, 1984). Due to the lack of records from the JCPVA, there are no concrete numbers by which to assess the definitive proof or amount of gentrification. Nonetheless, it can be suspected such a large investment in fixed capital spurred some sort of production-side gentrification. The Downtowner closed around 1991 after a fundraiser for "AIDS support services," as this was its last mention in the Courier-Journal (Neuhauser, 1991; Hu, 2016). Occupying a sliver of what is now known as Whisky Row, the Downtowner closed after the owner's new venture, the Connection, opened in 1988 to alleviate the overflow from the Downtowner's popularity (Hu, 2016). (The Connection is addressed later in this section.) Since the Downtowner closed before the window of available property value records, there is no way to accurately assess its position and/or contribution to gentrification. Nevertheless, the massive redevelopment project started in the 1980s certainly could have contributed.

“Tynker's" \& "Tynker's Too/The Rage" ranked third in the amount of mentions within the archives. Although seemingly two different bars, the addition of "Too" to the name signified its reopening at a new location after its first location faltered a bit economically. Originally, Tynker's - a country-themed lesbian bar-was located at 657 West Shipp Avenue, which is now next to University of Louisville affiliated campus housing (Egerton, 1994a; 1994b). The earliest mention within the Williams-Nichols collection indicates the first version may have opened in 1993. The last news article mention of Tynker's was in early 1996, indicating it perhaps closed soon thereafter, due to what co-owner Tina Bell cited as lesbians earning less and having less leisure time than gay men, in addition to lesbians preferring to spend money at bars geared towards gay men (Egerton, 1994b; Courier-Journal, 1996a). Tynker's Too/The Rage applied for its liquor license at 319 East Market Street in mid-1996, soon after its original location closed (Courier- 
Journal, 1996b). Tynker's Too/The Rage operated for a few years, yet seems to not have made it long after, judging by the lack of mentions in both the Courier-Journal and the Williams-Nichols collection. The last feature of the lesbian bar indicates adding drag king and drag queen shows, as well as a showroom (The Rage) may have helped its popularity (Rosen, 1999). There are no specific mentions or clues as to why it may have closed.

In terms of property valuation, there is only one date with a record within the 1996-1999 timeframe when Tynker's Too/The Rage probably occupied the space. In 1997, the total property value was assessed at $\$ 262,800$, with $\$ 81,000$ in land value and $\$ 181,800$ in property improvements. Although there are no records before 1997 for this parcel, Tynker's Too added their showroom, The Rage, in 1997, which suggests Tynker's Too did make large capital investments in the land. After Tynker's Too/The Rage, the property value, even with any investments from the bar, only increased meagerly. In 2002 , the property value stood at $\$ 282,600$, only a $\$ 19,800$ increase (solely in property improvements) in five years. If there even is an argument for Tynker's Too/The Rage starting or contributing to gentrification, it would be a very weak one indeed.

The fourth in most mentions in the Williams-Nichols archives was "Connection." This bar, unlike the others, remained in business for quite some time, spanning from 1988 - opened by the same owners as the Downtowner - to its closing in 2015; it still remains one of the most wellknown, multi-generational LGBTQ+ bars in the city, as well as the entire state of Kentucky (and a constant mention in regional LGBTQ+ advertising pamphlets) (Shafer, 2015; Hu, 2016). The closing of the Connection at its 120-130 South Floyd Street location came after the owners sold the property to an out-of-state developer, citing their ages as a factor in selling the property (Shafer, 2015). Due to Connection's impressive presence for such a long time, a deluge of property value information might be expected. However, there is not a single record with the JCPVA at the time 
of this writing for either of the listed addresses. This is quite perplexing and serves to question the absence of data for this particular parcel of land. Without it, there is no way to definitively assess Connection's contribution to or impact from gentrification.

The fifth most-mentioned bar in the Williams-Nichols collection is "Murphy's," also known as "Murphy's Upstairs," “Upstairs," or "Murphy’s Place.” The particular history of Murphy's Place is a complicated one, involving aggressive redevelopment efforts, relocation, and rebranding for the gay community in Louisville. Michael Murphy opened "Murphy's Place" around 1987 at 410 West Market Street; this first iteration of Murphy's Place was a generic "neighborhood bar" located downtown, with no explicit affiliation with the LGBTQ+ community (Peterson, 1987). In a relatively short period of time, Murphy's Place suffered from capital disinvestment in the surrounding area, which attracted the sights of city and private developers, eager to transform downtown Louisville into a professional business skyline. Since Murphy's Place refused to sell its parcel for the planned "Capital Holding" headquarters, this attracted the attention of the "Louisville Urban Renewal Commission," which filed a condemnation suit against Murphy's Place and two other establishments (Shafer, 1989). While the other properties eventually acquiesced, Murphy's Place held to its land claim when in 1990, the Louisville Urban Renewal Commission offered the property owner $\$ 400,000$ (Shafer, 1990). Today, the land on which the original Murphy's Place stood is recognizable to all who live in or have visited Louisville. Presently named the "Mercer Tower," it is the tallest building in the state of Kentucky, rising 35 stories and is an unmistakable fixture in the Louisville skyline. The behemoth of a building was part of a $\$ 12$ million redevelopment effort in the immediate area, not withstanding the $\$ 90$ million “Capital Holdings" skyscraper (Shafer, 1990). Through numerous sales and divisions, the building was named the "Aegon Center" in the late 1990s (McDonough, 1998), and now stands as the 
“Mercer Tower" (“Insider Louisville," 2013). In 1991, just as construction on the building was finishing, the property was sold for a total of $\$ 2,860,000$; certainly, Murphy's Bar did not contribute to this level of immense valuation, but it surely was a victim. In 2014 , the property stood at a valuation of $\$ 60,000,000$ with a land value of $\$ 1,954,620$ and improvements valued at $\$ 58,045,380$.

Displaced by government and private-sponsored gentrification, Michael Murphy relocated his bar and reopened in a much more appropriately-valued spot. Settling on 306 East Market Street, Murphy's Place (part 2) was founded in 1990 (Courier-Journal, 1990a). This time, it had embraced its explicitly new image as a gay bar that was a spot for "Softer music and an older crowd," (Egerton, 1994a). However, despite several years of business, Michael Murphy filled for chapter 13 bankruptcy on Murphy's Place in 1997, effectively closing its doors for the last time (CourierJournal, 1997). In the years between 1990 and 1997, there were no features about Murphy's Place that suggest it was not able to keep its doors open, or why. However, current property records suggest it may have met a similar demise as it did in 1990. Currently, the block that would have held Murphy's Place now hosts a parking lot, a parking garage, and a large multi-use structure for offices, known as the "Nucleus" building. As of 2015, its valuation stands at a total of $\$ 33,770,000$ ( $\$ 2,637,180$ in land value and $\$ 31,132,820$ in property improvements), a long shot from a modest bar's potential valuation. 


\section{Production-Side Data: Highlands Neighborhood}

\section{Big Bar}

The location of 1202 Bardstown Road, currently occupied by Big Bar, has had numerous occupants since 1980. In 1981, it was a country music bar named "Davern's Tavern" (Rutherford, 1981). Davern's Tavern held the spot until “Ann E's Tavern” was established in 1987, which was reviewed as a "sleepy" tavern (Courier-Journal, 1987; Peterson, 1988). In 1990, Ann E's Tavern gave way to "Jeffrey's" described as a "little tavern" primarily focused on local music performances and light fare (Courier-Journal, 1990b; Puckett, 1993). In 2003, "Cribstone Pub" debuted its reopening at 1202 Bardstown Road, serving a mid-priced range of seafood (Reigler, 2003). "NV Tavern" replaced the Cribstone Pub in 2007 and was a community bar that served a variety of cocktails, food, and entertainment for "20-somethings to AARP members," (CourierJournal, 2007; Harris, 2008). In 2010, the "F.A.B.D. Smokehouse" (short for Frankfort Avenue Beer Depot, named after its main location on Frankfort Avenue) opened a second location in 1202 Bardstown Road, serving smoked meats and beer on tap (McMahan, 2010). Big Bar did not claim the space until 2012, coming a long way from the space's beginnings as a country tavern (LEO Weekly, 2012; Havens, 2013).

Big Bar is notably an LGBTQ+-affiliated bar. Yet, the owner, Kevin Bryan, has attempted to broaden Big Bar's appeal to all members of the community, disavowing any openly or primary LGBTQ+ focus:

Owner Kevin Bryan has also been saddled with the label "gay bar," but says it just doesn't begin to describe his business.

"Our customers are about 70 percent gay, but what sets Big Bar apart is that it's a comfortable, cozy neighborhood bar for everyone," he says. "Big Bar is for people — gay, straight, black, white, Latino. We welcome all, and people feel like it's their bar. They have a sense of ownership." (Havens, 2013) 
Nevertheless, Big Bar is a major fixture amongst the LGBTQ+ patrons in the Highlands neighborhood as well as Louisville at large. Big Bar is an LGBTQ+ bar, its status as such noted in several news reports: "[Big Bar] ...caters to the LGBT community ("WHAS," 2016); a site in the Brown-Forman employee LGBT pride celebration (Havens, 2016b); a recipient of flowers from local faith leaders as condolences for the Pulse Nightclub shooting (McAlister, 2016); one of the new, younger gay bars (Keel, 2016); listed alongside Nowhere Bar as one of the "happening queer joints," when Louisville was ranked by Orbitz as number four in the world for the top ten "hottest gay destinations for 2016," (Heidemann, 2015); an essential gay bar in the Highlands (Johnson, 2014); a favorite gay locale for pride festivities (Marcus, 2015); a new and upcoming gay bar (LEO Weekly, 2012); and even involved in fundraising efforts for the Fairness Campaign (a local LGBTQ+ rights advocacy group) through the show Big Brother (Vess, 2012). Big Bar has also been a sponsor-participant in the Louisville Pride Festival and the Kentuckiana Pride Festival (Louisville Pride Foundation, n.d.).

However, there have also been mentions of Big Bar without its LGBTQ+ affiliation, being featured in drink recommendations and various community events (Havens 2016a; Havens, 2016c; Westbrook, 2016; Adams, 2015; Garcia, 2015; Havens, 2015; Gerber, n.d.; Courier-Journal, 2014; Havens, 2014). The ability of Big Bar to be seen as both LGBTQ+ and not reveals its status as LGBTQ+-affiliated.

In its relatively recent history, Big Bar has established itself as an anchor amongst LGBTQ+-affiliated bars in Louisville. Yet, this same short history has yielded little information in terms of property value. When the property was sold to the current owners, its value was assessed. Since there were no improvements in the land and property during the sale, the valuation remained the same in 2012 as it was in 2006 , holding steady at $\$ 125,000(\$ 78,010$ in improvements 
and $\$ 46,990$ in land value). Thus, without a more updated property valuation (expected in 2017), the effect of Big Bar's presence and any effect on Big Bar the surrounding area has is yet to be determined. However, it can be noted that over time, the property upon which Big Bar is currently located experienced a wave of gentrification between 2001 and 2006 (see Table 5.0). As such, Big Bar can be viewed as having inherited a gentrified location.

\section{Nowhere Bar}

Nowhere Bar, located at 1133 Bardstown Road, started in April 2013 after taking the place of the local health food store "Amazing Grace," which had existed some 15 years before. The owners' mission when opening Nowhere Bar was to provide a space where LGBTQ+ folks are welcome, yet is open to all: “This bar doesn't need a label. This is a bar for the community of the Highlands and all of Louisville," (Havens, 2013). The imaging model embraced by Nowhere Bar demonstrates the tendency of bars to cater to a larger population instead of building for a specific community, seen also with Big Bar.

However, despite the attempts of dismissing its status primarily as a LGBTQ+ bar, it has operated as an undeniable fixture of the LGBTQ+ community in Louisville. Nowhere Bar has been a spot of numerous LGBTQ+ events and titles in Louisville, including a Brown-Forman LGBT employee pride celebration (Havens, 2016b); a recipient of flowers from Louisville faith leaders after the Pulse Nightclub shooting in Orlando (McAlister, 2016); being listed as one of the "happening queer joints" when Louisville was ranked fourth in the world's top "10 hottest gay destinations for 2016," by Orbitz (Heidemann, 2015); a sponsor-participant at both Louisville Pride and the Kentuckiana Pride Festival (Louisville Pride Foundation, n.d.); a bar with LGBTQ+ attendees "that can dramatically change from hour to hour," (Keel, 2016); a bar ranked as a gay 
bar, yet noting as an aside: 'Nowhere is not a 'gay bar' (we won't tell if you don't), they would rather be labeled as an alternative bar," (Johnson, 2014); and a gay bar, where "the actual gay-tostraight ratio on a given weekend is about 50/50," (Myers, 2013).

Yet, Nowhere Bar has also been featured in numerous events and awards that do not mention its affiliation with the LGBTQ+ community. These events and awards include being named as "Best Place to Dance" by Louisville Magazine in 2016 (Myers, 2016); "Best Happy Hours" in Louisville by StyleBlueprint (Gerber, n.d.); a feature along the world's "largest and oldest annual zombie walk," (Adams, 2015); a locale for dance parties (O’Neil, 2013); and an ugly sweater party (“WDRB," 2015). Even Nowhere Bar's description is devoid of any mention of its LGBTQ+ status:

At Nowhere Louisville we pride ourselves on being open to everyone. We live and breathe the "Keep Louisville Weird" mantra, and feel so appreciative to be a part of the highlands neighborhood; where bar-hopping is not only available, but a way of life. Every day brings new excitement, so whether you want to dance the night away, shoot a few games of pool, or chill on our patio we're confident you'll feel right at home. Welcome to Nowhere: it's like no where you've been before. (Nowhere Bar Louisville, 2017)

While there certainly have been more Nowhere Bar activities and features than those listed, it is apparent that Nowhere bar, while claiming complete neutrality, is known at the very least a LGBTQ+-friendly bar. In short, it is known to be strongly affiliated with the LGBTQ+ presence both hyper locally in the Highlands neighborhood and more broadly in the city of Louisville.

In its transition from a health foods store to a dance club and bar, Nowhere Bar has only had one property value assessment performed in its four-year existence, with another expected to be completed in 2017. The property valuation on Nowhere Bar's property at 1133 Bardstown Road stood at a total of $\$ 399,850$, with $\$ 276,360$ in improvements to the property and a land value of $\$ 123,490$. This is approximately a $29 \%$ jump in valuation since its previous record in 2007 when Amazing Grace held its spot. The cause for increase was not the land valuation (which only 
increased by $\$ 1,900)$, but rather property improvements, which increased $\$ 87,260$, a total of $98 \%$

of the total increase in property value. Compared to the property investment in 2007 , there was a $46 \%$ increase. This increase stands in stark comparison to the history of the property as a whole in less than 20 years. In 1996, the total property value for improvements was $\$ 106,360$ and only increased by $\$ 82,740$ over the course of 11 years. The large investment made by Nowhere Bar in its property improvements suggests a growing rent gap, which could be fueling gentrification.

\section{Chill Bar}

One of the newest editions to the LGBTQ+ bar scene in Louisville is Chill Bar at 1117 Bardstown Road. Chill Bar was opened in 2013, adding to Nowhere Bar and Big Bar's presence (Gayle, 2016). However, unlike Nowhere Bar and Big Bar, Chill Bar was established from the outset specifically as a gay bar (although it certainly remains open to all):

Born out of our love of good friends, good drinks and good times, Chill BAR Highlands is a favorite gay bar and night spot known as the place where fun happens. Come enjoy our large full service patio bar or chill in the atmosphere of a historic building in the Highland neighborhood. (Chill Bar, 2013)

Beyond these sources, the amount of history of Chill Bar-or of the property itself-in publicly available records is small. However, the property value records provide the relatively short commercial history of 1117 Bardstown Road. Up until 2011, 1117 Bardstown Road was classified as a residential property. In 2011, it was rezoned as a commercial property and was thus reassessed. At the time of reassessment, since there was some change, the total valuation increased from $\$ 133,050$ (\$99,300 in improvements and $\$ 33,750$ in land value) to $\$ 192,730$ with the land value remaining steady and the improvements increasing to $\$ 158,980$, a $60 \%$ increase. Pictures made available by the Jefferson Country Property Valuation Administration indicate 1117 
Bardstown Road operated under the new commercial zoning as "Highland Liquors," a liquor store from 2011 to 2013, when Chill Bar became the new tenant.

Between the 2012 and 2015 assessments, Chill Bar had become the occupier of the property and thus made respective changes. Between the property value assessments in 2012 and 2015, the total value of the property increased $\$ 131,000$, a $49 \%$ increase in three years. Since the land value remained the same during this period $(\$ 54,360)$, the property improvement value was the source of the increase, suggesting an acceleration in the rent gap. This intense revving up of property value, specifically improvements, indicates Chill Bar's accelerative impact on gentrification on Bardstown Road. The $\$ 131,000$ increase in property value over three years under the ownership of Chill Bar suggests it has had the most impact on gentrification amongst the LGBTQ+-affiliated bars and clubs in the Highlands neighborhood. 


\section{Further Analysis: Disparities}

This study has revealed the mixed and complex legacy of openly and affiliate LGBTQ+ bars in Louisville. The bars used in the analysis - admittedly only a fraction of the total bars that have existed with ties to the Louisville LGBTQ+ community - represent the many possibilities of the transformations of urban space: some were gentrified, others cause gentrification, some remained constant, and others cannot be truly analyzed. Nonetheless, a more in-depth analysis focusing on the methodology of gentrification and the nuances of urban space reveal the larger implications of the overall condition of non-straight space in Louisville.

The analysis shown demonstrates there has certainly been production-side gentrification to occur amongst openly and affiliated LGBTQ+ spaces in Louisville in the past thirty years. Such bars as the first Murphy's Place, Tryangles, Big Bar, Nowhere Bar, and Chill Bar have clear relations with gentrification when assessed from a production-side standpoint. Yet, while the first Murphy's Place and Tryangles were negatively impacted, Nowhere Bar and Chill bar have contributed to gentrification by widening the rent gap. Big Bar has only benefited from the gentrification that took place before it. Still, for some bars in this analysis, definitive analysis remains out of reach. This is the case for the Downtowner, where Courier-Journal articles, not concrete property values, reveal possible effects of gentrification in the area with massive capital projects. Tynker's Too, however, was able to escape the grip of gentrification and caused relatively none itself. Unfortunately, due to the lack of property value records and press articles, the history of Discovery remains left to be explored. Despite these mixed individual conclusions, the history of gentrification amongst these spaces reveal fractures amongst bar patrons able to participate or claim and maintain these spaces. 


\section{Production versus Consumption in Louisville}

Throughout this study, I remark how the methodology for obtaining consumption-side data for gentrification is almost insignificant for Louisville; however, that is only when viewing the data in isolation. While I set out to examine gentrification from both perspectives in the field, I was only able to utilize the property values as direct explanations for gentrification (or the absence thereof). Yet, the lack of change in consumption measures might suggest something entirely different than just whether gentrification occurred or is affecting the examined affiliated or openly LGBTQ+ spaces in Louisville.

When the consumption-side data is compared alongside the production-side data to form a comprehensive picture of gentrification, the ability of individuals to participate or claim and maintain urban space amongst these affiliated and openly LGBTQ+ spaces is revealed. As Louisville as a whole has not shown any significant increases in the demographics that would lead to increased consumption, and as some affiliated and openly LGBTQ+ spaces (especially those that stand today) are benefiting from or contribute to gentrification, then who is able to participate in these spaces or claim and maintain them?

In all of the bars studied (for which there was sufficient evidence) it was found that based on production-side factors, two bars (Nowhere Bar and Chill Bar) potentially increased or contributed to gentrification by making fixed capital investments in space. These spacial improvements and the maintenance of such investments made may result in the cost of such improvements (and the resulting increasing property taxes) being passed onto the consumer in the form of higher prices (Colman, 2005; Brown-Saracino, 2009). In the cases of Tryangles, where it was affected by surrounding gentrification, and of Big Bar, benefiting from an already-gentrified location, these locations may also pass increased property taxes and maintenance costs to the 
consumers. Yet, as average median income has been falling in Louisville over thirty years and employment remains relatively the same, which customers are picking up the tab?

Gentrification, a phenomenon where the economic position of a place is increased due to property investments, is happening with at least the two extant openly or affiliated LGBTQ+ bars, Chill Bar and Nowhere Bar. The economic standing of these locales has increased, even though the relative consumption power of Louisville citizens is not increasing. This disparity suggests there is a disparate impact within these LGBTQ+ spaces on who can and cannot claim, maintain or participate. Without increases in consumption power to keep up with gentrification at these locations, the amount of individuals who frequent these bars that can claim or maintain these spaces diminishes. Potentially, the number of people who can go to these bars and afford the services may also decrease. What's left is an increasingly more expensive LGBTQ+ venue, economically accessible only to a smaller segment of the population.

\section{Open or Affiliated?}

There is another area of potential disparate impact of gentrification amongst these locales due to the difference between designating between "openly" and "affiliated" LGBTQ+ bars in this study. While the flyers and news articles for the bars used in this study from 1980 to 1990 openly claimed their queer — or at least gay_-identity (the first Murhpy’s Place not withstanding), two of the bars in this study that have been established within the past few years have worked to distance themselves from an explicit $L G B T Q+$ identity. As such, they remain "affiliated." They accept their LGBTQ+ status in practice while officially distancing themselves from it. Big Bar and Nowhere Bar in particular fit this description. The question arises as to why such bars would behave in such a manner. 
Looking back to the owners' claims in news accounts, it is clear the owners have wanted to create and retain an image of being bars for "all." From Big Bar's owner, Kevin Bryan (requoted from an earlier section):

"Our customers are about 70 percent gay, but what sets Big Bar apart is that it's a comfortable, cozy neighborhood bar for everyone," he says. "Big Bar is for people — gay, straight, black, white, Latino. We welcome all, and people feel like it's their bar. They have a sense of ownership." (Havens, 2013)

And from David Mattingly, an owner of Nowhere Bar (re-quoted from an earlier chapter): “This bar doesn't need a label. This is a bar for the community of the Highlands and all of Louisville," (Havens, 2013). It is germane at this point in my analysis to mention these quotes were taken from a LEO Weekly piece titled "Nightlife guide 2013: Gay bar no more." In this piece, the author, Sara Havens, documents the rise of the numerous LGBTQ+-affiliated clubs in Louisville and how local LGBTQ+ leaders and the owners of these establishments praise the assimilation of LGBT persons into mainstream Louisville society to the point where they no longer need exclusive spaces. The assimilation argument refers to how those previously marginalized by legal discrimination have incorporated themselves as a part of mainstream society in light of non-discrimination laws and cultural changes. This argument of assimilation now rendering exclusively gay bars and queer spaces irrelevant for the modern economy is catching on in academia (Kelly, Carpiano, Easterbrook, \& Parsons, 2014; Ghaziani, 2015). Yet, while this narrative is tempting, it is critical to refocus on the question of who can claim urban space and how urban space is marketed.

When viewed in relation to the bars used in this study from the 1990s and 1980s, Nowhere Bar and Big Bar reveal something quite different in their economic appeal. While the bars of decades past were typically openly gay or queer, Big Bar and Nowhere Bar are not. Instead, Big Bar and Nowhere Bar present themselves so as to appeal to the entirety of Louisville. This tactic 
broadens the consumer base: why limit yourself to just the LGBTQ+ population in Louisville when you can appeal to all?

Marketizing these LGBTQ+-affiliated spaces for a larger population than just the LGBTQ+ community in Louisville creates another rift in the ability of LGBTQ+ folk who frequent these places to claim and maintain or participate in these spaces. In Bell and Binnie's (2006) piece, “Authenticating Queer Space: Citizenship, Urbanism, and Governance," they remark how "manifestations of gay consumer cultures - thoroughfares, street cafés, trendy bars, themed gay villages - ha[ve] driven the less-assimilated queers underground," (p. 180). In this study, the presentation of Nowhere Bar and Chill Bar not to LGBTQ+ folk, but to all while simultaneously maintaining the LGBTQ+ affiliation demonstrates how these "trendy bars" may tend to marginalize the rest of LGBTQ+ folk from participating in these spaces. In other words, if these bars work to distance themselves from an LGBTQ+ identity, what urban spaces are trans, queer, non-binary, and other folk able to claim or participate in? So not only does the gentrification of these bars pose a threat to how many people are able to participate in these spaces, but also it also limits who amongst LGBTQ+ people can claim, maintain, and participate. 


\section{Conclusion}

\section{Gentrification, Urban Space, and Louisville}

Cities are the prime location for identities to converge and be known. This is partly due to their size and diversity of population, the mass of the prolifically constructed environment, and the havens some cities may possess (Tonkiss, 2005). Yet, these urban spaces are also sites of contention and privilege over who can claim and maintain or participate in these spaces. When examining the process of gentrification amongst openly or at least affiliated LGBTQ+ spaces in Louisville, answers to who can claim and maintain or participate in these economically transformed spaces come to light.

Gentrification, understood as a process that increases the economic standing of property due to investments, influences which groups can claim, maintain, or participate in spaces. If a property becomes gentrified, its economic status increases, and thus reduces the ability of others to claim, maintain, and participate in urban spaces. When urban space, understood as a commodity subject to gentrification, is seen or constructed as non-straight space, differences emerge along the lines of sexual orientation and class status. As this study has demonstrated, some openly and affiliated LGBTQ+ bars and nightclubs in Louisville were able to weather gentrification, others were demolished by the process, and some perpetuate it. In these cases, the ability to claim and participate in urban space as LGBTQ+ matters along the intersections of space, gentrification, sexual orientation, and class. This is not to diminish the influence of other intersections such as race, ethnicity, ability status, etc. in LGBTQ+ urban space, but rather this study is only able to comment on specifically sexual orientation as it relates to class. Further research must be done to closely parse out other influences on Louisville LGBTQ+ individuals to claim space, especially amongst race and ethnicity, noting Louisville's historic discrimination in real estate practices that 
are still in de-facto effect today (Marshall, 2017; Lussenhop, 2016). A mixed-methods ethnography using the methods in this work along with semi-structured interviews would highlight more intersectional identities amongst LGBTQ+ individuals in Louisville and their influence in claiming, maintaining, and participating in urban space.

When studying this intersection of class and sexual orientation in gentrification, certain disparities arise. Since gentrification is a class-based process, the gentrification of Nowhere Bar, Chill Bar, and Tryangles (and potentially others) reveals how these spaces may become inaccessible to some amongst LGBTQ+ individuals not able to afford the economic externalities of gentrification. Furthermore, the attempted positioning of some of these bars as not explicitly queer in some way, and their increasing commodification may also cause another fracture between LGBTQ+ folk in who might actually be welcome or can economically participate. When an openly or affiliated LGBTQ+ bar becomes gentrified, who will still be able to participate? Additionally, who amongst LGBTQ+ folk would be able to maintain or reclaim these spaces? Soon, the LGBTQ+ community in Louisville will have to assess if these spaces will continue to be economically and culturally accessible to all, or if they will continue their march of gentrification; or, in the case of Tryangles, if it will continue to resist surrounding gentrification to keep its doors open. If these spaces fall to the allure of gentrification and change their socioeconomic level drastically, it would drive a wedge between the queer folk who can continue to afford the prices of a pricey cocktail and those who cannot. 


\section{References}

Adams, K. (2015, August 26). Bloody Saturday as zombies attack Louisville. Courier-Journal. Retrieved from http://www.courier-journal.com/story/life/events/2015/08/26/bloodysaturday-zombies-attack-louisville/32392239/

American Civil Liberties Union. (2017). Non-discrimination laws: State by state informationmap. Retrieved from https://www.aclu.org/map/non-discrimination-laws-state-stateinformation-map

Bailey, P. (2016, October 17). Louisville maintains perfect gay rights score. Courier-Journal. Retrieved from http://www.courier-journal.com/story/news/politics/metrogovernment/2016/10/17/louisville-maintains-perfect-gay-rights-score/92279854/

Bankruptcy Proceedings. (1997, June 1). Courier-Journal.

Bar Flyers. (1978-2001). Williams-Nichols collection, Archives and Special Collections, University of Louisville, Louisville, KY. 18 July 2016.

Beauregard, R. (1986). The chaos and complexity of gentrification. In N. Smith \& P. Williams (Eds.), Gentrification of the city (pp. 35-55). Boston, MA: Allen \& Unwin, Inc.

Bell, D., \& Binnie, J. (2006). Authenticating queer space: Citizenship, urbanism and governance. In A. Collins (Ed.), Cities of pleasure: Sex and the urban socialscape (pp. 177-190). London: Routledge.

Brown-Saracino, J. (2009). A neighborhood that never changes: Gentrification, social preservation, and the search for authenticity. Chicago: University of Chicago Press.

Chill BAR Highlands. (2013). Our Story. Retrieved from http://www.chillbarlouisville.com/ourstory.html

Clark, E. (1995). The rent gap re-examined. Urban Studies, 32(9), pp. 1489-1503.

Clark, E. (2010). The order and simplicity of gentrification - a political challenge. In L. Lees, T. Slater, \& E. Wyly (Eds.), The gentrification reader (pp. 24-29). London; New York: Routledge. (Original work published 2005)

Colman, D. (2005, September 4). Rich gay, poor gay. New York Times. Retrieved from http://www.nytimes.com/2005/09/04/fashion/sundaystyles/rich-gay-poor-gay.html?_r=0

Doan, Petra L. \& Higgins, H. (2011). The demise of queer space? Resurgent gentrification and the assimilation of LGBT neighborhoods. Journal of Planning Education and Research, 31(1), pp. 6-25.

Dumas, K. (1984, November 2). Main Street renaissance. Courier-Journal. 
Egerton, J. (1994a, June 25). Think pink: The clubs in Louisville's 'pink triangle' are the center of a gay nightlife extravaganza. Courier-Journal.

Egerton, J. (1994b, June 25). Low-key Tynker's struggles to stay afloat as a lesbian bar. CourierJournal.

Garcia, C. (2015, November 5). Louisville's happy hour guide. Louisville Magazine. Retrieved from https://www.louisville.com/content/louisvilles-ultimate-happy-hour-guide

Gayle, A.L. (2016, June 20). Bar, restaurant holds fundraiser to benefit Florida nightclub. WLKY. Retrieved from http://www.wlky.com/article/bar-restaurant-holds-fundraiser-tobenefit-florida-nightclub/3767990

Gerber, E. (n.d.). Louisville's best happy hours. StyleBlueprint. Retrieved from https://styleblueprint.com/louisville/everyday/happy-hours-by-day-kentucky/

Getting around town downtown Louisville: Shop till you drop! [advertisement for Strasberg's Sportswear]. (1988, October 12). Courier-Journal.

Ghaziani, A. (2015). Gay enclaves face prospect of being passé: How assimilation affects the spatial expression of sexuality in the United States. International Journal of Urban and Regional Research, 39(4), 756-771.

Gil, G. (1985, August 31). Patrons of gay bar call detectives' use of gloves demeaning. CourierJournal.

Glass, R. (2010). London: Aspects of change. In L. Lees, T. Slater, \& E. Wyly (Eds.), The gentrification reader (p. 7). London; New York: Routledge. (Original work published 1964)

Hammel, D. (2013). Gentrification and land rent: A historical view of the rent gap in Minneapolis. Urban Geography, 20(2), pp. 116-145.

Harris, J. (2008, April 30). The bar hopper. "Velocity.” In Courier-Journal.

Havens, S. (2013, May 1). Nightlife guide 2013: Gay bar no more. LEO Weekly. Retrieved from http://www.leoweekly.com/2013/05/nightlife-guide-2013-gay-bar-no-more/

Havens, S. (2014, April 30). Nightlife guide 2014: Bar guide. LEO Weekly. Retrieved from http://www.leoweekly.com/2014/04/nightlife-guide-2014-bar-guide/

Havens, S. (2015, November 25). Bar belle: Winter blows, but seasonal drinks do not. Insider Louisville. Retrieved from http://insiderlouisville.com/lifestyle culture/bar-belle-winterblows-seasonal-drinks-not/ 
Havens, S. (2016a, June 4). 15 Louisville bars celebrate international Negroni Week from June 6-12. Insider Louisville. Retrieved from http://insiderlouisville.com/lifestyle culture/15louisville-bars-celebrate-international-negroni-week-from-june-6-12/

Havens, S. (2016b, June 9). Brown-Foreman hosts annual Pride Celebration for employees and community partners. Insider Louisville. Retrieved from: http://insiderlouisville.com/lifestyle culture/brown-forman-hosts-pride-celebration-foremployees-and-community-partners/

Havens, S. (2016c, December 2). Bardstown Road Aglow will light up the Highlands on Saturday. Insider Louisville. Retrieved from http://insiderlouisville.com/lifestyle culture/31st-annual-bardstown-road-aglow-willlight-up-the-highlands-on-saturday/

Heidemann, J. (2015, December 26). 10 hottest gay destinations for 2016. [Blog post on behalf of Orbitz]. Retrieved from https://www.orbitz.com/blog/2015/12/look-ahead-10-hottestgay-destinations-2016/

Hu, J. (2016, July 17). Long-standing club's roots span decades. Courier-Journal.

Jefferson County Property Valuation Administrator. (2017). Property Listings. Retrieved from https://jeffersonpva.ky.gov/

Johnson, J. (2014, October 7). Louisville gay bars: The good, the bad, the ugly. Louisville Magazine. Retrieved from: https://www.louisville.com/content/louisville-gay-bars-goodbad-ugly

Keel, E. (2016, March 11). Walk in another man's heels: An inside look at drag and gender. LEO Weekly.

Kelly, B.C., Carpiano, R.M., Easterbrook, A., \& Parsons, J.T. (2014). Exploring the gay community question: Neighborhood and network influences on the experience of community among urban gay men. The Sociological Quarterly, 55, pp. 23-48.

Knopp, L. (1995). Sexuality and urban space: A framework for analysis. In D. Bell \& G. Valentine (Eds.), Mapping desire: Geographies of sexualities (pp.149-164). London: Routledge.

Knopp, L. (1998). Sexuality and urban space: Gay male identity politics in the United States, the United Kingdom, and Australia. In R. Fincher \& J. Jacobs (Eds.), Cities of difference (pp. 149-176). New York: Guilford Press.

Lauria, M., \& Knopp, L. (2010). Toward an analysis of the role of gay communities in the urban renaissance. In L. Lees, T. Slater, \& E. Wyly (Eds.), The gentrification reader (pp. 272284). London; New York: Routledge. (Original work published 1985) 
Legal Notices. (1990a, September 15). Courier-Journal.

Legal Notices. (1994, February 19). Courier-Journal.

Legal Notices. (1996b, July 15). Courier-Journal.

Louisville Pride Foundation. (n.d.). 2016 Sponsors. Retrieved from http://www.louisvillepride.com/sponsors/

Lussenhop, J. (2016, June 9). The legacy of segregation in Muhammad Ali's hometown. British Broadcasting Company. Retrieved from http://www.bbc.com/news/world-us-canada$\underline{36472454}$

Marcus, L. (2015, September 15). Where to eat, stay, and play in Louisville, Kentucky. Condé Nast Traveler. Retrieved from http://www.cntraveler.com/stories/2015-09-14/best-fooddrink-hotels-louisville-kentucky-pride

Marshall, A. (2017, March 22). Louisville's dividing lines: The results of redlining in the city. Louisville Magazine. Retrieved from https://www.louisville.com/content/dividing-lines

McAlister, S. (2016, June 14). Local faith leaders hand-deliver flowers to LGBT nightclubs. WHAS. Retrieved from http://www.whas11.com/news/local/local-faith-leaders-handdeliver-flowers-to-lgbt-nightclubs/244118140

McDonough, R. (1998, December 27). The 'mayor for life' steps down. Courier-Journal.

McDonough, R. (2000, November 8). Merger wins with solid majority. Courier-Journal.

McMahan, D. (2010, April 10). F.A.B.D. Smokehouse opens on Bardstown. “Scene.” In Courier-Journal.

Mel Golde Men’s Shoes, Inc. advertisement. (1980, March 30). Courier-Journal.

Myers, E. (2013, December 13). Best new bars of 2013. Louisville Magazine. Retrieved from https://www.louisville.com/content/best-new-bars-2013

Myers, E. (2016, May 24). Best of Louisville 2016 finalists announced. Louisville Magazine. Retrieved from https://www.louisville.com/content/best-louisville-2016-finalists$\underline{\text { announced }}$

Neuhauser, K. (1991, October 17). Tipsheet: Hoedown lowdown. Courier-Journal.

Nightlife. (2007, May 23). "Velocity.” In Courier-Journal.

Nowhere Bar Louisville. (2017). Retrieved from http://www.nowherelouisville.com 
O’Neil, L. (2013, November 7). Dance parties for every night of the week in Louisville. Louisville Magazine. Retrieved from https://www.louisville.com/content/dance-partiesevery-night-week-louisville

Peterson, J. (1987, August 1). Nightlife: Murphy's Place is probably the kind of bar you'd like. Courier-Journal.

Peterson, J. (1988, August 13). Nightlife: Tired of the trendy? These bars offer a nice change of pace. Courier-Journal.

Professional services: Night clubs. [Tynker's mention]. (1996a, February 18). Courier-Journal.

Puckett, L. J. (1993, August 21). Nightlife: Bigger and Bluer. Courier-Journal.

Reigler, S. (2003, June 13). The dish: Cribstone Pub moves to Bardstown Road. CourierJournal.

Restaurant Inspections. (1987, September 9). Courier-Journal.

Restaurant Inspections. (1990b, November 14). Courier-Journal.

Rosen, M. (1999, October 30). Kings of Louisville. Courier-Journal.

Rutherford, G. (1981, May 30). There's no Betty Lou, but Flabby's is No. 1. Courier-Journal.

Shafer, S. (1984, September 15). Developer fast becoming Louisville's Main man. CourierJournal.

Shafer, S. (1989, September 15). Norton building owners agree to sell it for planned Capital Holding project. Courier-Journal.

Shafer, S. (1990, March 6). Property owner agrees to sell last parcel for Capital Holding tower. Courier-Journal.

Shafer, S. (2015, December 2). Connection to be razed, reborn in new location. Courier-Journal.

Shots fired in Big Bar in the Highlands. (2016, July 8). WHAS. Retrieved from: http://www.whas11.com/news/local/shots-fired-in-big-bar-in-the-highlands/268204694

Smith, N. (1979). Toward a theory of gentrification a back to the city movement by capital, not people. Journal of the American Planning Association, 45(4), pp. 538-548.

Smith, N. (1987). Gentrification and the rent gap. Annals of the Association of American Geographers, 77(3), pp. 462-465. 
Smith, N., \& Williams, P. (1986). Alternatives to orthodoxy: Invitation to a debate. In N. Smith \& P. Williams (Eds.), Gentrification of the city (pp. 1-14). Boston: Allen \& Unwin, Inc.

Spooky spirits to drink for Halloween. (2014, October 29). Courier-Journal. Retrieved from http://www.courier-journal.com/story/life/food/2014/10/28/louisvilles-flavormanconjours-halloween-drinks-shares-recipes/18047389/

Staff. (2013, April 8). Updated: Aegon Center now 'Mercer Tower' (sort of) as new signage goes up. Insider Louisville. Retrieved from: http://insiderlouisville.com/business/aegon-centernow-mercer-tower-as-new-signage-goes-up/

Tonkiss, F. (2005). Embodied spaces: Gender, sexuality and the city. In Space, the city and social theory: Social relations and urban forms (pp. 94-112). Cambridge: Polity.

United States Census Bureau. (n.d.). Fact Finder Community Facts. Retrieved from http://factfinder.census.gov/faces/nav/jsf/pages/index.xhtml

. (1790-2010). Census of Population and Housing. Retrieved from https://www.census.gov/prod/www/decennial.html

United States Department of Labor. (2017). CPI Inflation Calculator. Retrieved from https://www.bls.gov/data/inflation calculator.htm

Vess, L. A. (2012, July 12). Big Brother 14: Wil Heuser houseguest profile. Big Brother Access. Retrieved from http://bigbrotheraccess.com/big-brother-14-wil-heuser-houseguestprofile-353405/

Westbrook, K. (2016, February 10). Set sail on a frozen drink bar crawl. LEO Weekly. Retrieved from http://www.leoweekly.com/2016/02/set-sail-frozen-drink-bar-crawl/

Williams, K. (1989). Demarginalizing the intersection of race and sex: A black feminist critique of antidiscrimination doctrine, feminist theory and antiracist politics. The University of Chicago Legal Forum (140), 139-167.

Writer's Choice 2012. (2012, September 19). LEO Weekly. Retrieved from: http://www.leoweekly.com/2012/09/writers-choice-2012/

Your ugly Christmas sweater can score you \$200. (2015, February 26). WDRB. Retrieved from http://www.wdrb.com/story/27612746/your-ugly-sweater-can-score-you-200 


\section{APPENDIX A}

Figure 1.0: Map of Louisville's "Urbanized Area," as defined by the U.S. Census Bureau in 1980

\section{Urbanized Areas}

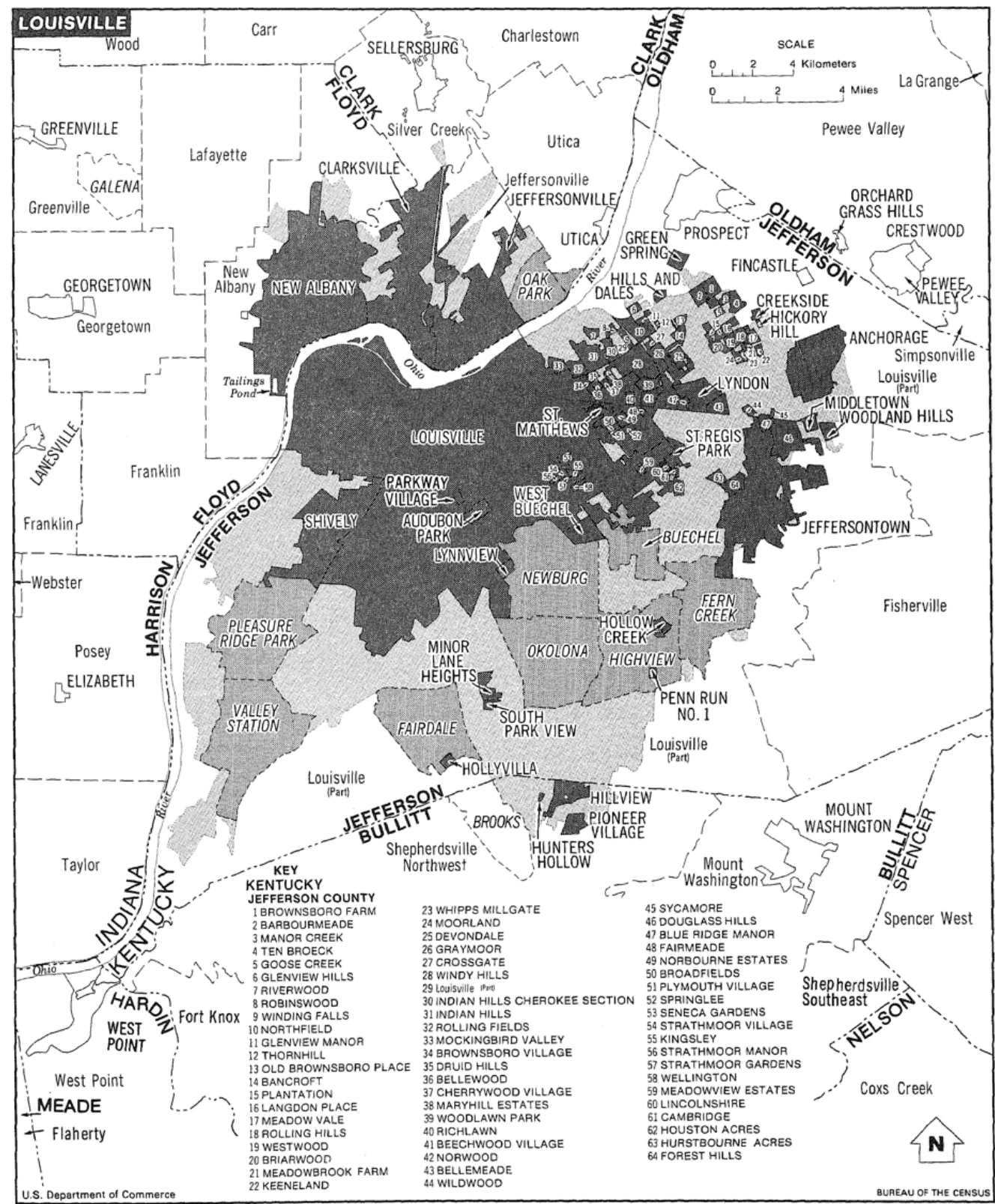




\section{Specific Census Data from 1980 to 2010}

1980 Census Data

Table 1.0: General Population ${ }^{8}$

\begin{tabular}{l|l|l|l|l} 
Total Spanish Origin & White & Black & Other & Total \\
\hline 4,168 & 550,548 & 107,058 & 4,625 & 666,399
\end{tabular}

Table 1.1 Education Attainment ${ }^{9}$

Sex, Age Male, 25+ Female, 25+

\begin{tabular}{lllllll}
\hline Years of College & $1-3$ & 4 & $5+$ & $1-3$ & 4 & $5+$
\end{tabular}

Completed

$\begin{array}{lllllll}\text { Total } & 25,886 & 16,732 & 16,908 & 28,969 & 13,463 & 11,355\end{array}$

Table 1.2: Total Education Attainment in Relation to Total Population ${ }^{10}$

\begin{tabular}{ll} 
Total Number of Any Completed College & 113,313 \\
\hline Percent of Total Population & $17 \%$
\end{tabular}

Table 1.3: Labor Force ${ }^{11}$

\begin{tabular}{l|l} 
Total Labor Force & 315,975 \\
\hline Total Employed (Civilian) & 289,755 \\
\hline Total Employed (Armed Forces) & 757 \\
\hline Percent Employed & $91.94 \%$
\end{tabular}

\footnotetext{
${ }^{8}$ Data obtained from 1980 Census, Table 31, p. [19-103]

${ }^{9}$ Data obtained from 1980 Census, Table 119, p. [19-142]

${ }^{10}$ (compiled from Table 1.1)

${ }^{11}$ Data obtained from 1980 Census, Table 120, p. [19-147]
} 
Table 1.4: Occupation Status ${ }^{12}$

\begin{tabular}{l|l|l} 
Type & Total Number & $\begin{array}{l}\text { Percent of Total Employed } \\
\text { Civilian Labor Force } \\
\text { (approximate) }\end{array}$ \\
\hline $\begin{array}{l}\text { Managerial and Professional } \\
\text { Specialty Occupations }\end{array}$ & 64,339 & $22 \%$ \\
\hline $\begin{array}{l}\text { Technical, Sales, and } \\
\text { Administrative Support } \\
\text { Occupations }\end{array}$ & 90,786 & $31 \%$ \\
\hline Service Occupations & 40,615 & $14 \%$ \\
\hline $\begin{array}{l}\text { Farming, Forestry, and Fishing } \\
\text { Occupations }\end{array}$ & 1,539 & $0.5 \%$ \\
\hline $\begin{array}{l}\text { Precision Production, Craft, and } \\
\text { Repair Occupations }\end{array}$ & 33,097 & $11 \%$ \\
\hline $\begin{array}{l}\text { Operators, Fabricators, and } \\
\text { Laborers }\end{array}$ & 59,379 & $20.5 \%$
\end{tabular}

Table 1.5: Median Incomes ${ }^{13}$

\begin{tabular}{l|l} 
& Overall \\
\hline Median & $\$ 68,590$ \\
Income for & \\
Families & \\
\hline $\begin{array}{l}\text { Median } \\
\text { Income for }\end{array}$ & $\$ 58,084$ \\
Households &
\end{tabular}

${ }^{12}$ Data obtained from 1980 Census, Table 121, p. [19-150]

${ }^{13}$ Data Obtained from 1980 Census, Table 130, p. [19-197] 


\section{Census Data}

Table 2.0: General Population ${ }^{14}$

\begin{tabular}{l|l|l|l|l|l|l} 
White & Black & $\begin{array}{l}\text { American } \\
\text { Indian/Eskimo/Aleut }\end{array}$ & $\begin{array}{l}\text { Asian/Pacific } \\
\text { Islander }\end{array}$ & $\begin{array}{l}\text { Hispanic } \\
\text { Origin }\end{array}$ & Other & Total \\
\hline 536,036 & 111,764 & 1,038 & 4,665 & 4,275 & 1294 & 654,797
\end{tabular}

Table 2.1: Education Attainment ${ }^{15}$

\begin{tabular}{|c|c|c|}
\hline $\begin{array}{l}\text { Age, } \\
\text { Sex }\end{array}$ & Years of College Completed & Total \\
\hline \multirow{6}{*}{$\begin{array}{l}\text { Male, } \\
25+\end{array}$} & Some college, no degree & 37,336 \\
\hline & $\begin{array}{l}\text { Associate's Degree (both occupational } \\
\text { and academic) }\end{array}$ & 9,014 \\
\hline & Bachelor's & 27,031 \\
\hline & Master's & 9,393 \\
\hline & Professional School & 5,818 \\
\hline & Doctorate & 1,604 \\
\hline \multirow{6}{*}{$\begin{array}{l}\text { Female, } \\
25+\end{array}$} & Some college, no degree & 45,432 \\
\hline & $\begin{array}{l}\text { Associate's Degree (both occupational } \\
\text { and academic) }\end{array}$ & 13,275 \\
\hline & Bachelor's & 23,014 \\
\hline & Master's & 12,251 \\
\hline & Professional School & 2,302 \\
\hline & Doctorate & 598 \\
\hline
\end{tabular}

Table 2.2: Education Attainment in Relation to Total Population ${ }^{16}$

\begin{tabular}{l|l} 
Total Number of Any Completed College & 104,300 \\
\hline Percent of Total Population & $16 \%$
\end{tabular}

Table 2.3: Labor Force ${ }^{17}$

\begin{tabular}{l|l} 
Total Labor Force & 331,754 \\
\hline Total Employed (Civilian) & 310,447 \\
\hline Total Employed (Armed Forces) & 715 \\
\hline Percent Employed & $93.8 \%$
\end{tabular}

${ }^{14}$ Data obtained from 1990 Census, General Population Information, Table 5, p. 166

${ }^{15}$ Data obtained from 1990 Census, Social and Economic Characteristics, Table 31, p. 1229

${ }^{16}$ (obtained from Table 2.1)

${ }^{17}$ Data obtained from 1990 Census, Social and Economic Characteristics, Table 33, p. 1527 
Table 2.4: Occupation Status ${ }^{18}$

\begin{tabular}{l|l|l} 
Type & Total Number & $\begin{array}{l}\text { Percent of Total Employed } \\
\text { Civilian Labor Force } \\
\text { (approximate) }\end{array}$ \\
\hline $\begin{array}{l}\text { Managerial and Professional } \\
\text { Specialty Occupations }\end{array}$ & 78,764 & $25 \%$ \\
\hline $\begin{array}{l}\text { Technical, Sales, and } \\
\text { Administrative Support } \\
\text { Occupations }\end{array}$ & 105,243 & $34 \%$ \\
\hline Service Occupations & 41,384 & $13 \%$ \\
\hline $\begin{array}{l}\text { Farming, Forestry, and Fishing } \\
\text { Occupations }\end{array}$ & 2,386 & $1 \%$ \\
\hline $\begin{array}{l}\text { Precision Production, Craft, and } \\
\text { Repair Occupations }\end{array}$ & 33,589 & $11 \%$ \\
\hline $\begin{array}{l}\text { Operators, Fabricators, and } \\
\text { Laborers }\end{array}$ & 49,081 & $16 \%$
\end{tabular}

Table 2.5: Median Incomes ${ }^{19}$

\begin{tabular}{l|l} 
& Overall \\
\hline Median & $\$ 70,943$ \\
Income for & \\
Families & \\
\hline Median & $\$ 53,032$ \\
Income for & \\
Households &
\end{tabular}

${ }^{18}$ Data obtained from 1990 Census, Social and Economic Characteristics, Table 34, p. 1676

${ }^{19} 1990$ Census, Social and Economic Characteristics, Table 3, p. 59 


\section{Census}

Table 3.0: General Population Information ${ }^{20}$

\begin{tabular}{l|l|l|l|l|l|l|l|l} 
White & $\begin{array}{l}\text { Black or } \\
\text { African } \\
\text { American }\end{array}$ & $\begin{array}{l}\text { American } \\
\text { Indian } \\
\text { and } \\
\text { Alaska } \\
\text { Native }\end{array}$ & Asian & $\begin{array}{l}\text { Native } \\
\text { Hawaiian } \\
\text { and } \\
\text { Other } \\
\text { Pacific } \\
\text { Islander }\end{array}$ & $\begin{array}{l}\text { Some } \\
\text { other } \\
\text { race }\end{array}$ & $\begin{array}{l}\text { Two } \\
\text { or } \\
\text { more } \\
\text { races }\end{array}$ & $\begin{array}{l}\text { Hispanic } \\
\text { or }\end{array}$ & $\begin{array}{l}\text { Latino } \\
\text { (of any } \\
\text { race) })^{21}\end{array}$ \\
\hline 582,641 & 131,239 & 1,681 & 9,772 & 261 & 4,808 & 10,233 & 12,782 & 740,635
\end{tabular}

Table 3.1: Education Attainment in Relation to Total Population ${ }^{22}$

\begin{tabular}{l|l} 
Enrolled in college or graduate school & 39,764 \\
\hline Percent with Bachelor's Degree or Higher & $24.3 \%$
\end{tabular}

Table 3.2: Labor Force ${ }^{23}$

\begin{tabular}{l|l} 
Total Labor Force & 378,602 \\
\hline Total Employed (Civilian) & 377,749 \\
\hline Total Employed (Armed Forces) & 853 \\
\hline Percent Employed & $95.1 \%$
\end{tabular}

Table 3.3: Median Incomes ${ }^{24}$

\begin{tabular}{l|l} 
& Total (in 2016 dollars) \\
\hline Median Income for Families & $\$ 71,362$ \\
\hline Median Income for Households & $\$ 57,733$ \\
\hline Median Income for Nonfamily Households & $\$ 35,340$
\end{tabular}

\footnotetext{
${ }^{20}$ Data obtained from 2000 Census, Summary Population and Housing Census, Table 18, p. 294

${ }^{21}$ This category in the 2000 Census is not tabulated into the total population of races.

22 Data obtained from 2000 Census, Summary Social, Economic, and Housing Characteristics, Table 34, p. 385

${ }^{23}$ Data obtained from 2000 Census, Summary Social, Economic, and Housing Characteristics, Table 36, p. 449

${ }^{24}$ Obtained from 2000 Census, Summary Social, Economic, and Housing Characteristics, Table 37, p. 481
} 


\section{Census}

Table 4.0: General Population ${ }^{25}$

\begin{tabular}{l|l|l|l|l|l|l|l|l} 
White & $\begin{array}{l}\text { Black or } \\
\text { African } \\
\text { American }\end{array}$ & $\begin{array}{l}\text { American } \\
\text { Indian } \\
\text { and } \\
\text { Alaska } \\
\text { Native }\end{array}$ & Asian & $\begin{array}{l}\text { Native } \\
\text { Hawaiian } \\
\text { and } \\
\text { Other } \\
\text { Pacific } \\
\text { Islander }\end{array}$ & $\begin{array}{l}\text { Some } \\
\text { other } \\
\text { race }\end{array}$ & $\begin{array}{l}\text { Two } \\
\text { or } \\
\text { more } \\
\text { races }\end{array}$ & $\begin{array}{l}\text { Hispanic } \\
\text { or } \\
\text { Latino } \\
\text { (of any } \\
\text { race) }\end{array}$ & Total \\
\hline 421,439 & 136,705 & 1,532 & 12,903 & 398 & 10,487 & 13,873 & 26,790 & 597,337
\end{tabular}

Table 4.1: Education Attainment ${ }^{27}$

\begin{tabular}{l|l|l|l|l|l|l|l|l} 
Age, Sex & $\begin{array}{l}\text { Male, } \\
25+\end{array}$ & & & & $\begin{array}{l}\text { Female, } \\
25+\end{array}$ & & & \\
\hline $\begin{array}{l}\text { Years of } \\
\text { College } \\
\text { Completed }\end{array}$ & $\begin{array}{l}\text { Some } \\
\text { college, } \\
\text { no } \\
\text { degree }\end{array}$ & $\begin{array}{l}\text { Associate's } \\
\text { Degree }\end{array}$ & Bachelor's & $\begin{array}{l}\text { Graduate or } \\
\text { Professional } \\
\text { Degree }\end{array}$ & $\begin{array}{l}\text { Some } \\
\text { college, } \\
\text { no } \\
\text { degree }\end{array}$ & $\begin{array}{l}\text { Associate's } \\
\text { Degree }\end{array}$ & Bachelor's & $\begin{array}{l}\text { Graduate o1 } \\
\text { Professiona } \\
\text { Degree }\end{array}$ \\
\hline Total & 42,206 & 13,254 & 32,105 & 21,970 & 50,726 & 17,819 & 34,629 & 26,160
\end{tabular}

Table 4.2: Education Attainment in Relation to Total Population ${ }^{28}$

\begin{tabular}{l|l} 
Percent of Total Population of Bachelor's & $28 \%$ \\
Degree or Higher &
\end{tabular}

\footnotetext{
${ }^{25}$ Obtained from https://factfinder.census.gov/faces/tableservices/jsf/pages/productview.xhtml?src $=\mathrm{CF}$ ${ }^{26}$ This category in the 2010 Census is not tabulated into the total population of races.

${ }^{27}$ Obtained from https://factfinder.census.gov/faces/tableservices/jsf/pages/productview.xhtml?src $=\mathrm{CF}$ ${ }^{28}$ Ibid
} 
Table 4.3: Labor Force ${ }^{29}$

\begin{tabular}{l|l} 
Total Labor Force & 314,664 \\
\hline Total Employed (Civilian) & 285,463 \\
\hline Total Employed (Armed Forces) & 440 \\
\hline Percent Employed & $90.8 \%$
\end{tabular}

Table 4.4: Occupation Status ${ }^{30}$

\begin{tabular}{l|l|l} 
Type & Total Number & $\begin{array}{l}\text { Percent of Total Employed } \\
\text { Civilian Labor Force } \\
\text { (approximate) }\end{array}$ \\
\hline $\begin{array}{l}\text { Management, Business, Science, } \\
\text { and Arts Occupations }\end{array}$ & 99,784 & $35 \%$ \\
\hline Service Occupations & 48,300 & $17 \%$ \\
\hline Sales and Office Occupations & 69,708 & $24 \%$ \\
\hline $\begin{array}{l}\text { Natural Resources, Construction, } \\
\text { and Maintenance Occupations }\end{array}$ & 20,292 & $7 \%$ \\
\hline $\begin{array}{l}\text { Production, Transportation, and } \\
\text { Material Moving Occupations }\end{array}$ & 47,379 & $17 \%$
\end{tabular}

Table 4.5: Median Incomes ${ }^{31}$

\begin{tabular}{l|l} 
& Total (in 2016 dollars) \\
\hline Median Income for Families & $\$ 66,741$ \\
\hline Median Income for Households & $\$ 51,194$ \\
\hline Median Income for Nonfamily Households & $\$ 31,430$
\end{tabular}

${ }^{29}$ Obtained from https://factfinder.census.gov/faces/tableservices/jsf/pages/productview.xhtml?src $=\mathrm{CF}$

${ }^{30}$ Ibid.

31 Ibid. 
Table 5.0: Jefferson County Property Valuation Administrator Property Value Assessments for Selected Bars

\begin{tabular}{|c|c|c|c|}
\hline PROPERTY NAME & $\begin{array}{l}\text { ASSESSMENT } \\
\text { YEAR TOTAL } \\
\text { PROPERTY VALUE }\end{array}$ & LAND VALUE & $\begin{array}{l}\text { PROPERTY } \\
\text { IMPROVEMENTS }\end{array}$ \\
\hline \multirow{5}{*}{$\begin{array}{l}\text { Nowhere Bar (1133 } \\
\text { Bardstown Road) }\end{array}$} & 1996: $\$ 151,970$ & $\$ 45,610$ & $\$ 106,360$ \\
\hline & 2000: $\$ 172,110$ & $\$ 45,610$ & $\$ 126,500$ \\
\hline & 2002: $\$ 272,510$ & $\$ 83,410$ & $\$ 189,100$ \\
\hline & 2007: $\$ 310,690$ & $\$ 121,590$ & $\$ 189,100$ \\
\hline & 2013: \$399,850* & $\$ 123,490^{*}$ & $\$ 276,360 *$ \\
\hline \multirow{4}{*}{$\begin{array}{l}\text { Chill Bar (1117 } \\
\text { Bardstown Road) }\end{array}$} & $2007: \$ 133,050$ & $\$ 33,750$ & $\$ 99,300$ \\
\hline & 2011: $\$ 192,730$ & $\$ 33,750$ & $\$ 158,980$ \\
\hline & 2012: $\$ 269,000^{*}$ & $\$ 54,360 *$ & $\$ 214,640 *$ \\
\hline & 2015: $\$ 400,000^{*}$ & $\$ 54,360^{*}$ & $\$ 345,640^{*}$ \\
\hline \multirow{5}{*}{$\begin{array}{l}\text { Big Bar (1202 } \\
\text { Bardstown Road) }\end{array}$} & 1994: $\$ 24,580$ & $\$ 13,580$ & $\$ 11,000$ \\
\hline & 2000: $\$ 13,580$ & $\$ 13,580$ & $\$ 0$ \\
\hline & 2001: $\$ 29,180$ & $\$ 13,580$ & $\$ 15,600$ \\
\hline & 2006: $\$ 125,000$ & $\$ 46,990$ & $\$ 78,010$ \\
\hline & 2012: $\$ 125,000^{*}$ & $\$ 46,990^{*}$ & $\$ 78,010^{*}$ \\
\hline \multirow[t]{5}{*}{$\begin{array}{l}\text { Tryanlges (209 South } \\
\text { Preston Street) }\end{array}$} & $\begin{array}{l}2001 \text { (January): } \\
\$ 180,800 *\end{array}$ & $\$ 108,000^{*}$ & $\$ 72,800^{*}$ \\
\hline & $\begin{array}{l}2001 \text { (December): } \\
\$ 230,400^{*}\end{array}$ & $\$ 108,000^{*}$ & $\$ 122,400^{*}$ \\
\hline & 2004: $\$ 313,000^{*}$ & $\$ 131,860^{*}$ & $\$ 181,140^{*}$ \\
\hline & 2008: $\$ 603,080^{*}$ & $\$ 421,940^{*}$ & $\$ 181,140^{*}$ \\
\hline & 2014: $\$ 477,130 *$ & $\$ 477,130^{*}$ & $\$ 0 *$ \\
\hline $\begin{array}{l}\text { Discovery Nightclub } \\
\text { and Bar (116 East } \\
\text { Main Street) }\end{array}$ & $\begin{array}{l}\text { NO DATA } \\
\text { AVAILABLE }\end{array}$ & $\mathrm{N} / \mathrm{A}$ & $\mathrm{N} / \mathrm{A}$ \\
\hline $\begin{array}{l}\text { The Downtowner } \\
\text { Complex (105 West } \\
\text { Main Street) }\end{array}$ & $\begin{array}{l}\text { NO DATA } \\
\text { AVAILABLE }\end{array}$ & $\mathrm{N} / \mathrm{A}$ & $\mathrm{N} / \mathrm{A}$ \\
\hline \multirow{2}{*}{$\begin{array}{l}\text { Tynker's Too/The } \\
\text { Rage (319 East } \\
\text { Market Street) }\end{array}$} & 1997: \$262,800* & $\$ 81,000^{*}$ & $\$ 181,800^{*}$ \\
\hline & 2002: $\$ 282,600$ & $\$ 81,000$ & $\$ 201,600$ \\
\hline $\begin{array}{l}\text { Connection (120-130 } \\
\text { South Floyd Street) }\end{array}$ & $\begin{array}{l}\text { NO DATA } \\
\text { AVAILABLE }\end{array}$ & N/A & N/A \\
\hline
\end{tabular}




\begin{tabular}{|l|l|l|l|}
\hline & & & \\
\hline $\begin{array}{l}\text { Murphy's Place (306 } \\
\text { East Market Street) }\end{array}$ & $\begin{array}{l}\text { NO DATA } \\
\text { AVAILABLE }\end{array}$ & N/A & N/A \\
\hline
\end{tabular}

Note: Additional information on JCPVA property evaluation procedures ${ }^{32}, 33$

${ }^{32}$ In the Louisville Metro area, the Jefferson County Property Valuation Administration (JCPVA) holds the authority on assessing private, commercial and residential properties within the jurisdiction of the Louisville-Jefferson County Metropolitan Government Balance. Commercial property valuations are performed at least once every four years at a minimum (KRS 132.690 (1)). However, commercial property may be assessed "when a property sells, a building or wrecking permit is issued, a property is damaged, or by request of property owner," in addition to when there are any changes in the zoning type and level of the property.

In order to assess a commercial property at "fair market value," the JCPVA utilizes three different approaches. Depending on the current position in the market a property is at the time of assessment, the JCPVA will use the appropriate method. In the "Market (Sales) Approach," JCPVA assesses a property's value based upon the fair market price for a similarly situated property at the time of sale. This method depends on a database built from market sales, the surrounding area, improvements, and the state of the property and uses an algorithm to assess a property's value based on these characteristics of the property being sold and those that are similar. The second approach, titled "Cost Approach" is a more direct comparative method of assessing value. According to JCPVA's website, "The cost approach value is based on the principle of substitution, for example, a rational, informed purchaser would pay no more for a property than the cost of building a replacement with similar function." Additionally, this method takes into account "age, depreciation," and the arbitrary distinction of "estimates of functional and economic obsolescence," as determined by the firm "Marshall \& Swift." The last method by which commercial property is assessed in Louisville by the JCPVA is the "Income (or Capitalization) Approach." This approach is directly based upon the amount of income generated by the property in its functioning as a business. This process is dependent upon the ability of a property purchaser to invest an initial amount in buying the property and the potential future income it will produce. Thus, this method takes into account the present ability of the property to produce a profit and its potentiality in producing future income. According to the website, "The income (or capitalization) method of value is best suitable for assessing income producing properties," and thus is the focus of the tables and data produced in this thesis.

${ }^{33}$ Items appearing with an asterisk indicate property values when the bar in question occupied that space. 